\title{
ANALISIS HADITS DALAM PERMASALAHAN PERANCANGAN MASJID MODERN DI MALAYSIA
}

Nangkula Utaberta

Hafsah Othman

\author{
Jabatan Seni Bina, Fakulti Kejuruteraan dan Alam Bina, \\ Universiti Kebangsaan Malaysia, Bangi, Selangor Darul \\ Ehsan, Malaysia \\ e-mail: nangkula_arch@yahoo.com \\ Jabatan Seni Bina, Fakulti Kejuruteraan dan Alam Bina, \\ Universiti Kebangsaan Malaysia, Bangi, Selangor Darul \\ Ehsan, Malaysia \\ e-mail: hafsah6360@yahoo.com
}

\begin{abstract}
This paper tries to make a documentation and analysis based on the second source of Islam which is Prophetic traditions in providing an alternative approach for the design of modern mosques in Malaysia. This research is done by gathering traditions from the compilation of al-Bukhari and Muslim which are then being interpreted and used as a framework to answer different type of problem, issue, crisis in mosque design in Malaysia. The study is divided into two main sections. The first section contains issues and problems in mosque design in Malaysia while the second section try to analyze the compilation of hadith in attempt to view issue and problems in mosque design in Malaysia. It is expected that through this paper we can understand the use of Prophetic traditions as one of the main foundations and framework for the present and the future modern mosque designs in Malaysia.
\end{abstract}

Keyword: Prophetic tradition, modern mosque design, Islamic architecture

\begin{abstract}
Abstrak
Tulisan ini mencoba untuk mendokumentasikan dan menganalisis hadits Nabi Muhammad saw dalam memberikan sebuah alternatif pendekatan untuk perancangan masjid modern di Malaysia. Kajian dilakukan dengan mengumpulkan hadits-hadits kompilasi Bukhari dan Muslim yang kemudian diuraikan dan dijadikan kerangka rujukan untuk menangani pelbagai permasalahan dan krisis perancangan masjid yang terjadi di Malaysia. Kajian ini terbagi dalam dua bagian utama. Bagian pertama mengkaji mengenai berbagai isu dan permasalahan perancangan masjid di Malaysia. Bagian kedua terdiri dari dokumentasi dan analisis terhadap himpunan hadits-hadits berkenaan dalam menyingkapi pelbagai isu dan permasalahan perancangan masjid di Malaysia dan dunia. Diharapkan kajian ini dapat memberikan pemahamam mengenai penggunaan hadits sebagai salah satu pendekatan utama dan kerangka pertimbangan dalam penghasilan perancangan masjid modern di Malaysia untuk masa kini dan masa depan.
\end{abstract}

Kata kunci: Perancangan masjid modern, hadits, arsitektur Islam

\section{Pendahuluan}

Dalam tulisan yang berjudul Islam, Architecture and Globalization: Problematic and Prospects for Research in Indonesia, Darwis Khudori memaparkan pelbagai pemikiran, diskusi dan penulisan tentang arsitektur Islam dan arsitektur masjid dari dua persepsi utama. Persepsi pertama disebutnya sebagai critical perception, sementara yang kedua disebut sebagai ideological perception. Critical perception didefinisikan sebagai sebuah persepsi kritis berdasarkan pemikiran yang berasaskan pendekatan ilmiah, rasional, dan diskusi intelektual, sebagaimana pendapatnya berikut ini.

"We can call this perception "critical" because it is based on scientific methods, accumulation of knowledge and intellectual reflection (developed constantly and progressively in the West)".
Selanjutnya beliau mengkategorikan institusi seperti Aga Khan Award for Architecture atau pemikir arsitektur Islam dan arsitek seperti Oleg Grabar dan Mohammed Arkoun dalam kategori ini. Untuk gerakan Aga Khan sendiri, menurut Khudori gerakan ini memiliki tiga karakter. Karakter pertama adalah keterbukaan gerakan ini terhadap ahli dan pemikir di dalam (Muslim) dan di luar Islam (non-Muslim) seperti Kenzo Tange, Charles Jencks, Robert Venturi, di samping tokoh-tokoh Muslim seperti Seyyed Hossein Nasr dan Muhammad Fazlurrahman. Karakter kedua adalah bahwa gerakan ini mendasarkan pemikirannya pada sebuah elaborasi intelektual. Hal ini terjadi melalui kajian daripada pelbagai disiplin ilmu. Karakter yang ketiga, beliau sebutkan sebagai karakter yang "pemalu". Gerakan Aga Khan tidak berusaha menjadi sebuah sekolah pemikiran, namun 
ia secara longgar merupakan forum untuk melakukan refleksi, berdiskusi, bertukar ide dan pengalaman, serta penyelidikan bersama bagi pencarian pemecahan pelbagai permasalahan kaum Muslimin.

Sementara itu, persepsi yang kedua yaitu ideological perception, atau dalam bahasa lain Darwis menyebutnya sebagai Arabo-Islamist, didefinisikan sebagai sebuah persepsi ideologis yang didasarkan pada tiga alasan. Alasan yang pertama karena persepsi ini mengakui dan meyakini keberadaan dari arsitektur yang islami dan perlunya pengembangan dan pembangunan persepsi ini untuk melawan dominasi Barat. Alasan yang kedua adalah karena persepsi ini meyakini bahawa arsitektur Islam berasal dari nilai-nilai dan prinsip dasar Islam yang diturunkan dari al-Qur'an dan Hadits, sementara alasan yang ketiga adalah kenyataan bahwa kelompok ini dibentuk dalam sebuah kerangka politik oleh Arab Saudi. Walaupun dalam pelbagai penjelasannya Khudori dilihat lebih memihak kepada persepsi yang pertama sekaligus mengkritik pendekatan yang kedua, namun klasifikasi yang ia lakukan sangat penting bagi sebuah pemahaman dasar atau identifikasi terhadap pemikiran dan falsafah yang berkembang di dalam arsitektur Islam.

Di lain pihak, Ismail Serageldin ketika memperbincangkan tentang perancangan masjid sebagai salah satu elemen utama dalam arsitektur Islam telah mengklasifikasikan pendekatan yang digunakan ke dalam lima kategori, yaitu pendekatan popular (vernakular), tradisional, populis, adaptif-modern, dan pendekatan modern. ${ }^{2}$ Sementara itu, dari segi ruang cakupannya, Serageldin membedakan perancangan masjid ke dalam empat ruang lingkup, yaitu Major Landmark Structure, Community Center Complex, Small Local Mosque, dan Zawiyas. Melalui idea pembagian dan klasifikasi tersebut, menurutnya akan membantu secara lebih mudah menganalisis karakter dan cakupan dari sebuah masjid.

Menanggapi klasifikasi tersebut, Mohammad AlAsad dalam pendapatnya kemudian menyimpulkan klasifikasi tersebut kepada dua klasifikasi saja, sebagaimana dijelaskannya seperti berikut:

“...I suggest placing these categories within an even simpler system by dividing approaches to contemporary mosque into two groups: one that accept historical precedents as main source of inspiration for generation of form, and one that does not."

Kemas Madani pada penulisan yang lain juga berusaha menterjemahkan kembali fungsi masjid dan membagi masjid ke dalam dua jenis, yaitu masjid sebagai elemen lingkungan dan masjid sebagai pusat aktiviti dan tempat peribadatan. ${ }^{4}$

Hasan-Uddin Khan dalam penulisannya tentang masjid membuat lima klasifikasi terhadap masjid sebagai elemen utama dalam arsitektur Islam. Klasifikasi ini dilakukan berdasarkan kategori klien yang meminta pembangunan masjid tersebut. ${ }^{5}$ Klasifikasi tersebut dilakukan berdasarkan kategori pemilik yang meminta perancangan masjid itu. Klasifikasi tersebut adalah masjid dengan kepemilikan negara, pemerintah setempat, institusi, masyarakat desa, dan masyarakat luas. Karena melibatkan dokumentasi terhadap banyak masjid di pelbagai negara, maka klasifikasi ini sangat penting bagi perbendaharaan bahasa kita tentang perancangan masjid.

Tulisan ini mencoba untuk merekonstruksi dan menganalisis hadits untuk memberikan alternatif pendekatan untuk perancangan masjid modern di Malaysia. Kajian dilakukan dengan mengumpulkan hadits-hadits Bukhari dan Muslim yang kemudian diuraikan dan dijadikan kerangka rujukan untuk mengatasi pelbagai permasalahan dan krisis perancangan masjid yang terjadi di Malaysia. Kajian ini terbagi menjadi dua bagian utama. Bagian pertama mengandung kajian mengenai isu dan permasalahan perancangan masjid di Malaysia. Bagian dua terdiri dari dokumentasi dan analisis terhadap himpunan hadits yang berkaitan dalam menyingkapi pelbagai isu dan permasalahan perancangan masjid di Malaysia dan dunia. Diharapkan melalui kajian ini penggunaan hadits-hadits Nabi Muhammad saw dapat dipahami sebagai salah satu pendekatan utama dan kerangka pertimbangan untuk menghasilkan rancangan masjid modern di Malaysia di masa kini dan masa depan.

\section{Permasalahan Perancangan Masjid Modern di Malaysia}

Penulisan ini memperbincangkan permasalahanpermasalahan dalam perancangan masjid yang terdapat di Malaysia. Perbincangan ini terbagi ke dalam enam bagian, yaitu (1) permasalahan identitas dan rupa bentuk, (2) permasalahan kedudukan dan lokasi masjid, (3) permasalahan dalam pengkhususan dan perancangan ruang, (4) permasalahan jamaah dan pengguna terutamanya bagi golongan wanita, anakanak, remaja, dan orang dengan keterbatasan fisik, (5) permasalahan dalam keselamatan dan kawasan masjid, dan (6) permasalahan dalam pengurusan dan ekonomi masjid. Kajian ini diharapkan dapat mengungkapkan berbagai permasalahan yang terdapat di sebagian besar masjid di Malaysia.

\section{Permasalahan identitas dan rupa bentuk masjid di Malaysia}

Jika diamati dengan teliti pada kebanyakan masjid yang ada di Malaysia khususnya, sebagian besar mempunyai rupa tampilan bangunan yang hampir sama, yaitu mempunyai kubah besar bercorak, menara, ornamen interior yang berukir, dan sebagainya. Bentuk arsitektur yang sedemikian merupakan satu peniruan kepada bentuk arsitektur masjidmasjid di masa-masa terdahulu yang dianggap sebagai kejayaan Islam. Beberapa contohnya dapat 
dilihat pada perancangan Masjid Wilayah, Masjid Putra di Putrajaya, Masjid Sultan Salahuddin di Shah Alam, dan Masjid UTM di Johor (Gambar 1).

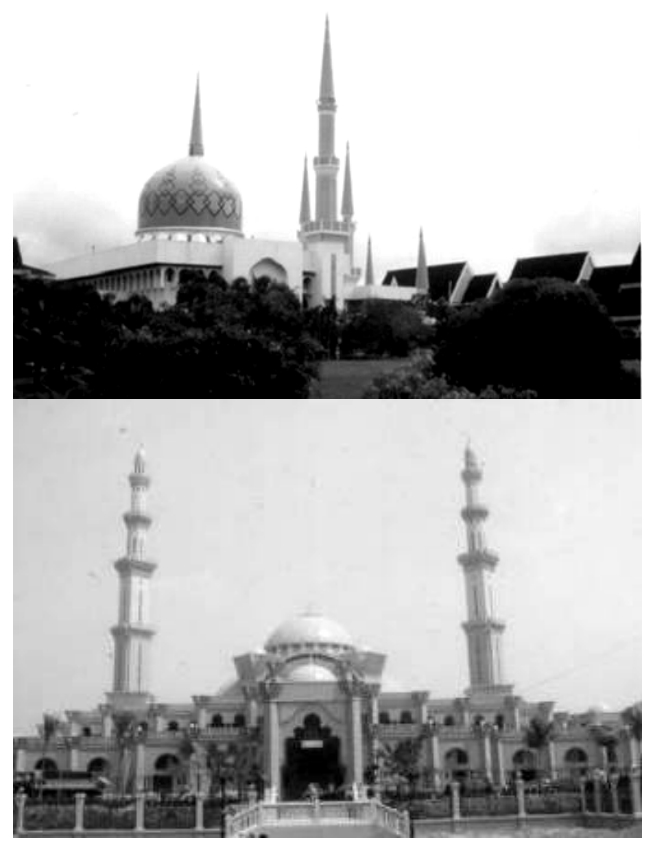

Gambar 1. Masjid UTM di Johor (atas) dan Masjid Wilayah di Kuala Lumpur (bawah) (Sumber: Hasil Dokumentasi)

Peniruan tampilan bentuk masjid terdahulu itu dilihat sebagai satu krisis identitas yang berasal dari perasaan rendah diri terhadap kehebatan bentuk arsitektur masa lampau yang lebih gemilang. Hasil perancangan bentuk arsitektural masjid terdahulu tersebut diadopsi dan dianggap mewakili satu bahasa arsitektur Islam yang resmi, terpilih, dan piawai dalam membahasakan arsitektur Islam. Permasalahan tersebut dilihat oleh Muhammad Tajuddin sebagai sebuah kekeliruan yang berasal dari sifat mental suatu bangsa yang dikatakan mengalami 'Middle Eastern Inferiority Complex'. Pemikiran semacam ini menganggap bahwa arsitektur masjid haruslah mencontoh arsitektur masjid dari Timur Tengah yang merupakan tempat lahirnya agama Islam. Kekeliruan tersebut jelas dikatakan oleh Muhammad Tajuddin sebagai berikut:

"The attitude thus prevailing seems to indicate that Muslims in Malaysia have an inferiority complex against the Middle East, the birthplace of Islam. I have no reservation for saying so because neither the Qur'an nor hadith of the Prophet Muhammad (peace be upon him) make any mention as to the required expression of the mosque to be from its birth place."

Masyarakat Malaysia sepatutnya bangga dengan identitas dan tampilan arsitektur yang telah diwarisi oleh generasi terdahulu, seperti yang dapat dilihat di Masjid Tradisional Kampung Laut di Kelantan dan Masjid Negara di Kuala Lumpur. Masjid Tradisional Kampung Laut telah dibangun ratusan tahun lalu dengan teknologi di masa tersebut yang ditampilkan dengan citra bangunan setempat seperti penggunaan bumbung berbentuk piramida, lantai yang ditinggikan dari permukaan tanah, dan sebagainya. Begitu juga dengan Masjid Negara yang mempunyai ciri-ciri bangunan setempat yang dapat dilihat pada penggunaan serambi, penataan ruang-ruang yang mempertimbangkan pengaliran udara yang baik, dibantu dengan penggunaan teknologi pada masa masjid itu dibangun. Kesan peniruan-peniruan tersebut menyebabkan negara ini mengalami kekeliruan identitas yang cukup serius, serta memberi kesan bahwa perkembangan citra arsitektur setempat telah terhambat disebabkan masuknya bahasa arsitektural luar yang asing di negara ini. Sehubungan dengan itu, penggunaan bahasa arsitektur setempat perlu ditekankan dalam setiap pembangunan masjid.

\section{Permasalahan kedudukan dan lokasi masjid di Malaysia}

Salah satu permasalahan utama yang dipertimbangkan oleh para jamaah untuk pergi ke masjid adalah jarak masjid dan lokasinya yang mudah dikunjungi. Kebanyakan masjid pada hari ini terutama yang terletak di kota dibangun di tempat yang jauh dari tempat berkumpul orang ramai atau pemukiman. Masjid yang dibangun jauh dari lokasi pemukiman menyebabkan jamaah harus menaiki kendaraan untuk ke masjid. Situasi ini dilihat pada Masjid Sultan Abdul Samad (Gambar 2) yang lebih dikenal dengan nama Masjid KLIA yang dibangun jauh dari pemukiman masyarakat dan penduduk sekitar, sebaliknya masjid ini dibangun berdekatan dengan bandar udara.

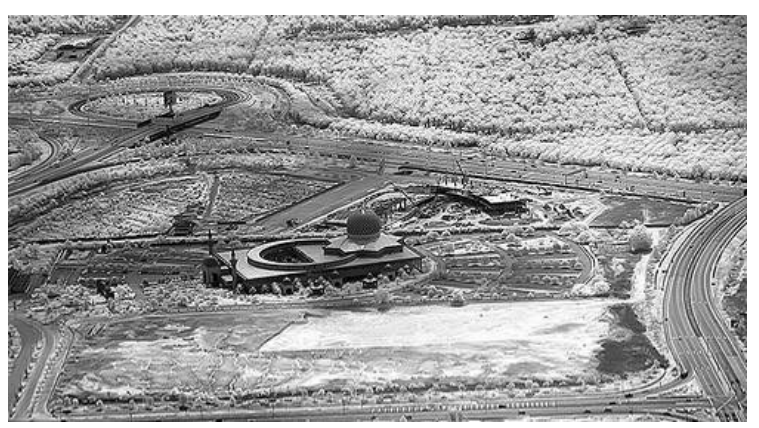

Gambar 2. Masjid Sultan Abdul Samad (Sumber: www.google.com)

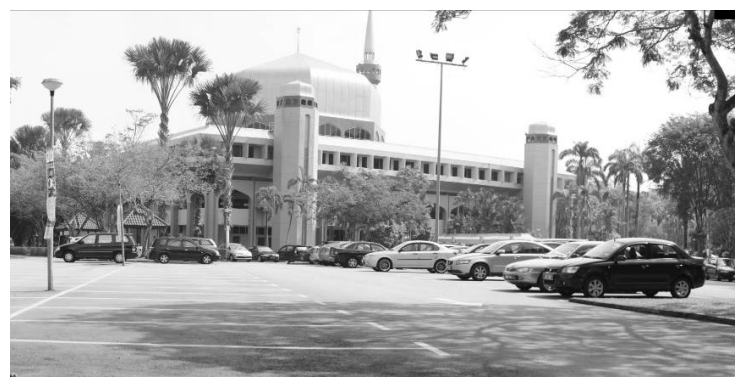

Gambar 3. Masjid UKM, Bangi (Sumber: Hasil Dokumentasi) 
Bagi masjid yang terletak di dalam kawasan kampus seperti Masjid Universiti Kebangsaan Malaysia (Gambar 3), kedudukannya yang strategis dan berdekatan dengan fakultas dan jalan utama kampus merupakan kelebihan karena senantiasa menjadi tempat persinggahan pelajar untuk mendiskusikan perkuliahan dan beristirahat selain untuk beribadat. Selain pelajar dan karyawan, Masjid UKM turut dikunjungi oleh masyarakat umum dan penduduk sekitar, terutama pada hari Jum'at dan hari raya kaum Muslim. Lokasi masjid yang strategis memberi kelebihan dalam memberikan kesempatan bagi lebih banyak orang untuk turut serta dalam berbagai aktivitas yang diselenggarakan para pengurus masjid.

\section{Permasalahan dalam pengkhususan dan perancangan ruang masjid}

Perancangan ruang yang teliti dan teratur perlu ditekankan dalam pembangunan sebuah masjid, terutama yang berkaitan dengan pemisahan ruang di antara pengguna laki-laki dan perempuan bagi semua aktivitas terutama saat shalat berjamaah, saat mengambil wudhu, atau dalam penggunaan kamar kecil. Muhammad Tajuddin menegaskan bahwa ruang shalat khusus bagi perempuan perlu disediakan serta dirancang khusus bagi perempuan sesuai dengan keperluannya, terutama bagi mereka yang memiliki keterbatasan fisik, bersama anak kecil, dan sebagainya. Begitu juga dengan kedudukan tempat wudhu bagi perempuan, sewajarnya diletakkan berdekatan dengan ruang shalat perempuan untuk memudahkan para wanita serta memberi kelonggaran kepada mereka untuk tidak berhijab di dalam kawasan

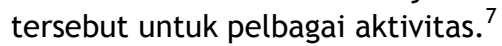

Di Masjid Universiti Kebangsaan Malaysia (UKM) di Bangi, permasalahan ini dapat menyulitkan para wanita yang bersama anak kecil, terutama apabila kedudukan tempat wudhu terletak jauh dari kamar kecil dan ruang shalat (Gambar 4). Jamaah wanita harus melalui koridor dan melintasi ruang memandikan jenazah untuk ke tempat wudhu, begitu juga dengan kamar kecil yang dicapai melalui ruang koridor yang turut digunakan oleh jamaah lelaki terlebih dahulu untuk ke kamar kecil.

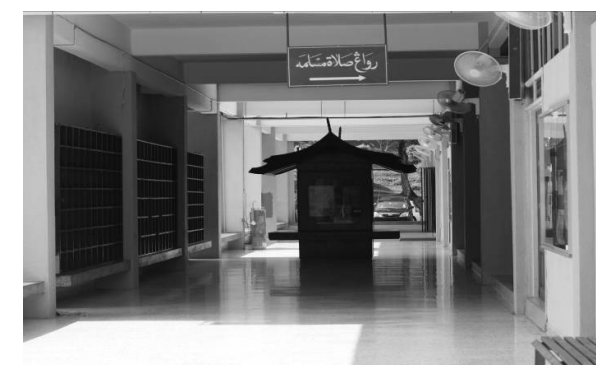

Gambar 4. Koridor utama yang menghubungkan ruang shalat wanita dengan kamar kecil, ruang wudhu, dan juga ruang memandikan jenazah di Masjid UKM
Isu kamar kecil turut menjadi perbahasan oleh Muhammad Tajuddin karena terdapat pendapat yang menyatakan bahawa kedudukan kamar kecil tidak boleh seatap dengan ruang shalat. ${ }^{8}$ Permasalahan ini kemungkinan disebabkan oleh keinginan untuk mengelakkan timbulnya pelbagai bau yang tidak menyenangkan. Sehubungan dengan itu, kedudukan kamar kecil perlu dirancang dengan pertimbangan aliran udara yang baik untuk mencegah bau yang tidak diinginkan di ruang shalat.

\section{Permasalahan jamaah dan pengguna}

Bagian ini menceritakan berbagai permasalahan yang berkaitan dengan jamaah dan pengguna masjid di Malaysia. Kajian ini tertumpu kepada tiga golongan yang kurang diberi perhatian dalam perancangan ruang-ruang di dalam masjid di Malaysia, yaitu golongan orang yang memiliki keterbatasan fisik, golongan remaja, dan anak-anak. Kajian ini diharapkan dapat memberi pemahaman tentang pentingnya mempertimbangkan keperluan ketiga golongan pengguna itu. Ini dikarenakan perancangan sebuah masjid sewajarnya memberi kenyamanan dan memenuhi keperluan semua lapisan masyarakat tersebut tanpa diskriminasi karena semuanya merupakan bagian dari kaum Muslim.

Setiap muslim berhak memakmurkan masjid, termasuk orang-orang yang memiliki keterbatasan fisik tersebut. Karena itu, kemudahan-kemudahan untuk berbagai golongan hendaklah disediakan serta dibantu oleh semua pihak. Terdapat sebuah hadits yang menceritakan bahwa orang yang memiliki keterbatasan fisik juga tidak mendapatkan perkecualian dalam menunaikan shalat berjamaah di masjid, selagi dari rumahnya dapat didengar suara adzan, seperti hadits Shahih Muslim berikut:

Diriwayatkan dari Abu Hurairah ra.: Seorang laki-laki buta pernah datang kepada Rasulullah saw dan bertanya, "Wahai Rasulullah, saya tidak punya penuntun untuk pergi ke masjid." Orang itu minta keringanan kepada Rasulullah saw untuk mengerjakan shalat di rumahnya saja. Beliau memperbolehkannya. Setelah pulang, orang tersebut dipanggil lagi dan beliau bertanya, "Apakah kamu mendengar seruan shalat (azan)?" Orang itu menjawab, "Ya." Beliau bersabda,

"Penuhilah panggilan itu (pergilah ke masjid).".

Hadits di atas jelas menyatakan kewajiban orang yang buta untuk datang berjamaah di masjid. Sehubungan dengan itu, Abu Saif berpendapat bahwa masjid haruslah mempertimbangkan golongan yang memiliki keterbatasan fisik tersebut untuk memudahkan pergerakan mereka. Bagi masjid-masjid besar yang bertingkat, sudah tentu permasalahan penyediaan lift, jalur kursi roda, dan semacamnya harus diutamakan sejak awal perancangan dan pembangunan masjid. ${ }^{10}$

Pada Masjid UKM juga tidak didapati adanya pengkhususan untuk orang yang memiliki keterbatasan fisik di tempat parkir kendaraan (Gambar 5). 
Selain itu, juga didapati jalur masuk dari area parkir ke dalam masjid juga tidak ramah bagi pengguna yang memiliki keterbatasan fisik, dimana ramp tidak tersedia di semua tempat yang mempunyai anak tangga. Remaja juga merupakan golongan pertengahan di antara anak-anak dan dewasa yang senantiasa aktif, bersifat ingin tahu, serta bersifat agresif. Oleh karena itu, perhatian dan didikan yang sempurna perlu diterapkan di dalam diri mereka dengan mendekatkan mereka dengan masjid. Golongan ini juga merupakan generasi akan datang yang akan membentuk masyarakat yang berciri keislaman, dan masjid merupakan pengantara misi tersebut.

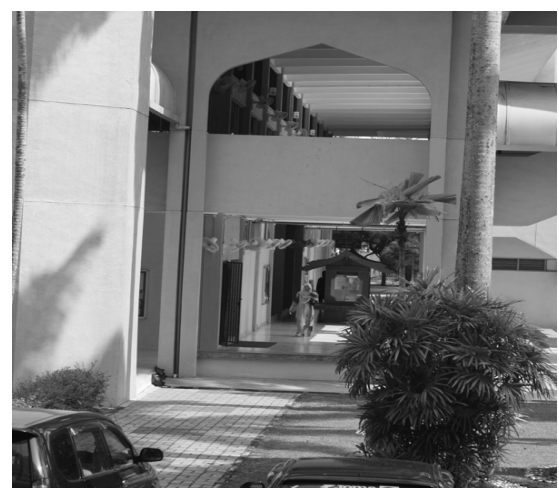

Gambar 5. Jalur ke dalam Masjid UKM didapati tidak ramah terhadap pengguna kursi roda (Sumber: Hasil Dokumentasi)

Untuk mendekatkan golongan remaja dengan masjid, perlu diwujudkan berbagai kemudahan yang diperlukan untuk aktivitas yang menjadi kegemaran mereka sebagai satu umpan untuk menarik minat mereka terhadap masjid, seperti yang dipaparkan oleh Abu Saif sebagai berikut:

“...Seterusnya, adalah pada mengimbangkan di antara kuliah-kuliah yang dekat dengan selera orang tua, dengan kuliah-kuliah yang menawan hati anak muda. Sediakan juga perkhidmatan yang anak muda 'mahu', sebagai 'umpan' untuk mereka diberikan apa yang mereka 'perlu'. Tuisyen, gelanggang sepakraga dan khidmat kaunseling adalah di antara perkhidmatan yang boleh dipertimbangkan..."11

Terwujudnya pelbagai kemudahan yang diperlukan oleh golongan remaja untuk aktivitas-aktivitas kegemaran mereka akan menjadikan mereka terbuka hatinya untuk mendatangi masjid. Secara tidak langsung, golongan ini akan berminat untuk menyertai pelbagai aktivitas lain yang bersifat keilmuan, disebabkan telah terwujudnya rasa kasih sayang dan cinta kepada masjid.

Lebih jauh, masjid juga sewajarnya bersifat ramah dengan keberadaan golongan tua dan dewasa yang bersifat positif dan penyayang terhadap golongan remaja. Sifat dan pekerti sedemikian juga dilihat sebagai satu kemampuan luar biasa yang mampu menarik mereka kepada masjid, seperti yang dinyatakan oleh Abu Saif sebagai berikut:
"Permulaan kepada langkah ini, adalah pada membentuk sikap positif orang-orang tua yang berada di masjid untuk menyapa dan bertanya khabar kepada anak-anak muda yang berkunjung. Kuasa kasih sayang masih belum mampu ditandingi oleh mana-mana kuasa lain. Rasa empati yang diperolehi oleh anak muda daripada sapaan orang tua berpangkat abang, bapa dan datuk kepada mereka, adalah sesuatu yang mudah diperolehi di gereja, tetapi jarang di masjid. Suatu tamparan buat kita semua."

"Jika di gereja, paderi akan berdiri di pintu mengucapkan penghargaan kepada satu demi satu 'jemaah'nya yang hadir. Di masjid kita, bisa sahaja orang yang keluar masuk masjid tidak pernah disedari oleh warga tetap masjid itu bermula daripada Imamnya hinggalah kepada jemaah di saf."12

Masjid yang ramah terhadap golongan remaja bukan saja berawal dari kemudahan yang disediakan, tetapi juga sifat mesra dan peduli dari para jamaah yang lain terhadap mereka ketika berjumpa di masjid tersebut.

Di Masjid UKM didapati tiada kemudahan khusus untuk aktivitas golongan remaja, kecuali area parkir yang luas dan mungkin dimanfaatkan untuk aktivitas bola keranjang dan badminton untuk rekreasi pada waktu petang. Pada bagian utara masjid ini juga disediakan beberapa buah gazebo tempat berteduh dan bersantai bersama keluarga di mana rimbunan pohon-pohon meneduhi kawasan sekitar yang menghijau ditumbuhi rumput.

Anak-anak merupakan calon generasi pengganti di masa yang akan datang yang menentukan corak kehidupan dan masa depan sebuah masyarakat. Sehubungan dengan itu, masyarakat perlu mengubah pandangan mereka terhadap anak-anak, dari seseorang yang tidak mengerti apapun, menjadi seseorang yang perlu diberi perhatian dan pendidikan yang seawal mungkin berkenaan dengan keagamaan dan fungsi masjid khususnya. Untuk itu, telah dipaparkan beberapa perkara oleh Abu Saif, seperti berikut:

"Ibu bapa harus diperingatkan tentang amalan sahabat yang tatkala membawa anak-anak mereka ke masjid, mereka juga membawa permainan agar anak-anak itu tadi boleh disibukkan dengan permainan tersebut tatkala solat atau kuliah pengajian berlangsung."

"Adalah tidak masuk akal untuk ibu bapa, AJK Masjid atau penceramah untuk meletakkan 'expectation' bahawa anak-anak boleh duduk diam mendengar ceramah seperti ibu bapa mereka. Justeru ibu bapa perlu mengambil inisiatif untuk membantu anak-anak duduk di dalam suasana masjid dengan ditemani oleh permainan-permainan yang sesuai (trompet semestinya tiada dalam senarai), atau buku-buku mewarna, bergantung kepada kecenderungan dan minat anak masing-masing."

"Manakala di pihak masjid pula, andai berkapasiti, boleh diusahakan bilik permainan yang sesuai dan selamat untuk anak-anak yang mempunyai pembesar suara untuk ibu-ibu yang meneman anak di bilik itu dapat mengikuti kuliah yang disampaikan. Padang permainan mini juga bukanlah suatu alternatif yang keterlaluan untuk dipertimbangkan. ${ }^{13}$

Saran dan masukan yang dinyatakan oleh Abu Saif seperti di atas bukanlah sesuatu yang mustahil 
untuk diaplikasikan dalam menggalakkan penyertaan golongan anak-anak di dalam aktivitas-aktivitas di masjid, hanya sedikit perubahan dan pengorbanan yang perlu dilakukan bagi perubahan di masa depan.

\section{Permasalahan keselamatan dan kawasan masjid}

Masjid yang berhasil dalam aktivitas kemasyarakatan dan ekonominya sudah pasti menggalakkan kehadiran banyak orang tanpa dibatasi waktu dan masjid tersebut akan beroperasi selama dua puluh empat jam. Masalah yang akan timbul dari penerapan hal ini ialah isu keselamatan masjid itu sendiri, termasuk keamanan terhadap pencurian peralatan masjid, uang zakat, infak, dan shadaqah orang banyak, dan sebagainya.

Berhubung dengan isu tersebut, masjid tersebut memerlukan pengawasan selama dua puluh empat jam dari pengurus masjid yang bertugas mengawasi keamanan masjid, selain juga berfungsi sebagai penerima tamu masjid yang datang sebagai musafir dan menumpang berteduh ataupun menyewa kamarkamar di masjid untuk bermalam dan sebagainya. Hal ini dilihat dapat menjaga hak masjid serta menggalakkan kehadiran para tamu ke masjid tersebut sekaligus meningkatkan pendapatan masjid tersebut. Terdapat juga situasi dimana masjid dipagar dan dikunci semasa bukan waktu shalat. Kejadian ini dilihat berlaku pada banyak masjid di Malaysia disebabkan tiadanya perhatian yang serius terhadap masjid oleh para pemegang kebijakan di masjid tersebut serta masyarakat di sekitarnya. Selain itu, timbul juga persoalan akan perlunya menyediakan pagar bagi sebuah masjid.

Persoalan ini dapat dijawab dengan melihat kepada fungsi masjid itu sendiri yang beroperasi bagi pengembangan masyarakat tanpa batasan usia dan juga waktu sebagaimana yang telah berlaku pada zaman Rasulullah saw. Sehubungan dengan itu dilihat keberadaan pagar bagi sebuah masjid tidak diperlukan karena menyebabkan timbulnya rasa perbedaan ruang kepada para pengunjung. Sehubungan dengan itu, pagar masjid dapat diganti dengan pelbagai perancangan penanda batas lain yang lebih ramah, seperti menanam pokok secara teratur dan apik untuk mendefinisikan kawasan masjid.

Sementara itu, kelengkapan masjid dan simpanan zakat dan infak yang ada di masjid seharusnya disimpan di tempat khusus yang cukup aman. Karena itu, ruang penyimpanan barang-barang berharga perlu dipersiapkan sebaik-baiknya, sehingga hak masjid dapat dijaga bagi keperluan masyarakat Muslim.

\section{Permasalahan ekonomi dan pengurusan}

Sebuah masjid memerlukan penjagaan dan pengurusan yang sewajarnya untuk memelihara kelancaran berbagai fungsinya, menjaga kebersihannya, memelihara harta yang dititipkan di dalamnya, dan sebagainya. Pengurusan dan penjagaan tersebut me- merlukan pembiayaan dan keuangan yang setimpal dengan pelaksanaan tugas-tugas itu. Sumber keuangan sebuah masjid biasanya diperoleh dari infak para jamaah. Namun begitu, pendapatan itu bisa jadi tidak mencukupi untuk pembiayaan kos pengurusan dan penjagaan masjid tersebut.

Sehubungan dengan itu, menurut Faizal Ridzuan Dato' Seri Mohd Najid Tun Razak telah melontarkan satu ide yang cukup baik semasa menjabat Timbalan Perdana Menteri dengan merancang agar masjid dijadikan pusat ekonomi kaum Muslim melalui pelbagai program yang berorientasi perniagaan daripada sekadar berfungsi sebagai tempat shalat berjamaah dan mendengar ceramah ${ }^{14}$. Di antara rancangan perniagaan oleh beliau ialah restoran, kelas kursus, kedai gunting rambut, pajak gadai Islam (ar-Rahnu), dan mikro kredit.

Menurut Faizal Ridzuan lagi, ide Dato' Seri Mohd Najid Tun Razak suatu ketika dahulu telah disambut baik oleh beberapa pengurus masjid di Malaysia dengan menjalankan pelbagai aktivitas yang berorientasikan perniagaan untuk memantapkan keuangan masjid ${ }^{15}$. Di antara masjid tersebut ialah Masjid Al-Qhufran yang terletak di Taman Tun Doktor Ismail di Kuala Lumpur. Sumber pendapatan masjid ini diperoleh dari mengelola perniagaan yang diusahakan sejak tahun 2004. Di antara sumber pendapatan masjid tersebut ialah ruang inap musafir, Dewan Konferen, Bilik Mesyuarat, Dewan Jamuan, Dewan Akad Nikah, Café Al-Ghufran, penyewaan tanah untuk antena komunikasi, serta kelas Fardu Ain dan Agama.

Faizal Ridzuan juga mendapati untuk berada pada tahap tersebut, pengurusan masjid itu sendiri hendaklah terdiri dari orang-orang yang berpengalaman dalam pengurusan dan pentadbiran ${ }^{16}$. Formula ini merupakan rahasia dari kejayaan Masjid AlGhufran (Gambar 6) dalam pengurusan sumber pendapatan seperti yang dikatakan oleh pengurus masjid tersebut, yaitu Haji Hassanuddin Ali.

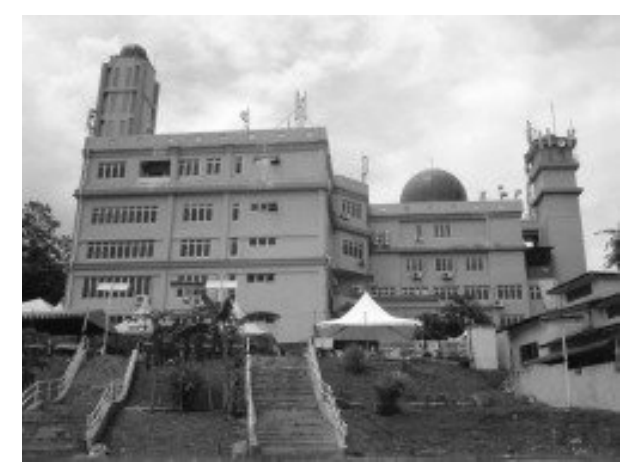

Gambar 6. Masjid Al-Ghufran di Taman Tuan Dr. Ismail (Sumber: Hasil Dokumentasi)

Selain aktivitas perniagaan yang dijalankan di masjid, terdapat juga rencana untuk mendokumentasikan khutbah Jumat yang disampaikan secara 
reguler. Teks khutbah Jumaat tersebut lalu dibukukan menjadi beberapa jilid. Buku tersebut dijual kepada masyarakat untuk menyampaikan kandungan khutbah tersebut ke segenap pelosok masyarakat Muslim lalu turut menyumbang pendapatan kepada masjid tersebut.

Menurut Salawati Haris, terdapat enam strategi yang boleh digunakan oleh pihak pengurus masjid dalam mengusahakan pendapatan bagi masjid, di antaranya ialah dengan mengadakan saham wakaf. Strategi tersebut ialah dengan menyewakan harta yang dimiliki oleh masjid tersebut kepada masyarakat umum bagi kegiatan-kegiatan tertentu, seperti menjalankan premis perniagaan dan sebagainya. Bagi masjid yang tidak mempunyai harta wakaf, boleh mengusahakan dengan mengadakan permohonan sumbangan para dermawan dengan menyatakan tujuannya secara jelas oleh Salawati Haris seperti berikut:

"Sumbangan wakaf yang jelas maksudnya ialah dengan menyatakan pendapatan yang disasarkan dan untuk tujuan apa. Contohnya, di Bandar Baru Bangi mensasarkan sebanyak RM 10,000 juta hasil sewa dari dua lot kedai yang memerlukan dana sebanyak RM 1 juta . Dengan itu dilancarkan dana saham wakaf untuk membeli bangunan dengan tujuan supaya bangunan itu dapat disewa dan menjana pendapatan berterusan kepada masjid." 17

Selanjutnya, menurut Salawati Haris cara meningkatkan pendapatan masjid juga dapat diusahakan dengan mengumpulkan dana masjid yang terkumpul dari semua masjid di Malaysia lalu membentuk sebuah lembaga di bawah satu entiti yang tidak terikat seperti Yayasan Pembangunan Ekonomi Islam (Yapeim) ${ }^{18}$. Dana tersebut dileburkan lalu keuntungan yang dihasilkan dikembalikan lagi kepada masjid-masjid tersebut.

Turut dirancang pula oleh Salawati Haris untuk membangun kompleks perniagaan di lokasi-lokasi strategis seperti di dalam kawasan masjid-masjid yang mempunyai ruang yang luas ${ }^{19}$. Selain itu juga, pembangunan masjid memerlukan perancangan yang teliti di kawasan baru perkotaan termasuk merancang kedudukannya yang strategis untuk mengerakkan ekonominya. Para pengambil kebijakan mengenai masjid pula perlu diberi wawasan lebih lanjut terhadap isu ini dengan mengadakan kunjungan ke masjid-masjid yang telah berhasil di dalam atau luar negeri.

\section{Analisis dan Penggunaan Hadits dalam Perancangan Masjid}

Penulisan ini bertujuan menganalisis nilai yang terkandung di dalam al-Hadits yang dapat dijadikan panduan dalam perancangan sebuah masjid. Pemilihan hadits adalah dari Shahih Bukhari dan Shahih Muslim karena ketinggian taraf hadits-hadits yang dikumpulkan berdasarkan kesahihannya. Himpunan hadits Shahih Bukhari merupakan yang diakui paling tinggi kesahihannya di antara enam kitab hadits yang termasyhur. la juga dianggap rujukan utama di dalam Islam setelah kitab suci al-Qur'an. Sementara itu, himpunan hadits Shahih Muslim juga dianggap kedua termulia setelah himpunan hadits Shahih Bukhari. Kesahihan suatu hadits menjadi keutamaan karena hadits-hadits tersebut akan menjadi pegangan dan asas dalam menentukan fatwa, hukum, dan sebagainya.

Selain itu, penulisan ini juga turut membahas masalah dalam penentuan identitas dan tampilan bagi masjid dan penyelesaiannya menurut haditshadits yang shahih sebagai rujukan dan mengukuhkan perbincangan. Penulisan di dalam bab ini juga akan memperbincangkan pemilihan lokasi dan kedudukan masjid yang sesuai dengan keperluan masyarakat Muslim saat ini dengan merujuk kepada keperluankeperluan masyarakat terdahulu terhadap fungsi masjid dan fungsi sekitarnya yang membantu kepada perkembangan masyarakat ke arah memakmurkan masjid serta memaksimalkan fungsi masjid itu sendiri. Turut menjadi fokus penulisan adalah isu pengguna dan jamaah di masjid serta keperluan-keperluan yang sewajarnya disediakan untuk memudahkan pergerakan dan kelancaran sesuatu aktivitas yang dijalankan serta kenyamanan penggunanya. Penulisan ini juga turut memperbincangkan isu pengkhususan ruang tertentu yang diperlukan oleh pengguna berdasarkan beberapa aktivitas yang memerlukan pengkhususan tersebut.

\section{Identitas dan rupa bentuk}

Malaysia dilihat telah mengalami permasalahan identitas dalam perancangan masjid seperti pada masjid Tengku Sulaiman (Gambar 7) menurut pandangan Mohamad Tajuddin ${ }^{20}$ disebabkan kegagalan para pemikir Muslim untuk menerjemahkan pendekatan yang sesuai dengan era modern pada hari ini ke dalam perancangan masjid. Jika diteliti di dalam kumpulan hadits Rasulullah saw, terdapat beberapa hadits yang mempunyai persamaan dalam pengertian isu yang berkaitan dengan identitas ini yang berguna untuk dijadikan panduan untuk perancangan masjid.

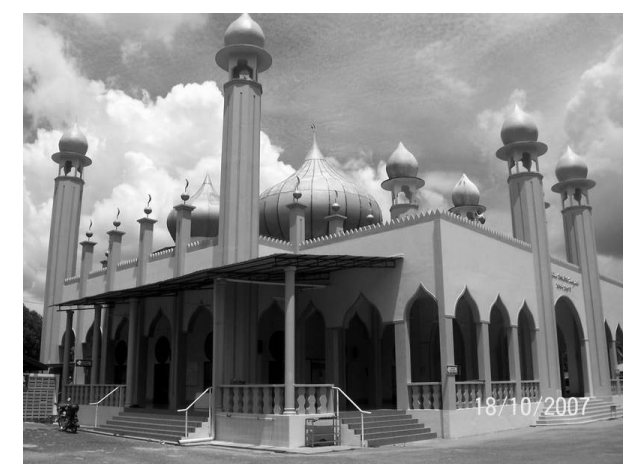

Gambar 7. Masjid Tengku Sulaiman, Bentong, Pahang (Sumber: Hasil Dokumentasi) 
Citra dan tampilan masjid di suatu tempat hendaklah mencerminkan dan menonjolkan satu pengenalan kebudayaan dari masyarakat setempat itu. Dengan menonjolkan kebudayaan yang dimiliki oleh masyarakat setempat itu pastinya akan menjadi penanda kekhasan daerah itu. Langkah tersebut harus dianggap penting oleh semua yang terlibat dalam pembangunan sebuah masjid. Perlu diingat bahwa membanggakan sesuatu yang bukan hak dan kepunyaan adalah sebuah penipuan seperti yang telah dinyatakan di dalam hadits berikut:

Yang bermaksud: Diriwayatkan dari Asma' ra.: Seorang perempuan pernah menghadap Nabi saw seraya berkata, "Saya seorang perempuan yang dimadu, berdosakah saya berpura-pura menampakkan kepuasan dengan harta suami yang tidak diberikan kepada saya?" Rasulullah s.a.w. bersabda, "Orang yang merasa puas dengan harta yang tidak diberikan kepadanya, sama halnya dengan orang yang memakai dua lembar kain palsu (tipuan)."21

Dalam pembangunan sebuah masjid, isu penting yang turut dibincangkan adalah biaya pembangunan yang tinggi, sehingga kadang kala mencapai angka yang dapat dikategorikan sebagai satu kemubaziran. Kemubaziran sedemikian rupa mampu dielakkan seandainya elemen-elemen tambahan yang berunsurkan ornamen semata-mata dan tidak berfungsi pada bangunan masjid dibuang dan sebagai gantinya kesederhanaan diamalkan. Perbuatan ini bersesuaian dengan gaya hidup islami seperti yang diamalkan oleh Rasulullah saw seperti yang telah dinyatakan di dalam hadits-hadits berikut:

Yang bermaksud: Diriwayatkan dari Muhammad bin Ziyad: Aku pernah mendengar Abu Hurairah berkata, "Ketika melihat seorang laki-laki, pembesar Bahrin, mengulurkan kainnya sampai menyapu tanah, aku berkata, 'pembesar datang, pembesar datang.'” Rasulullah saw bersabda, "Sesungguhnya, Allah tidak akan memandang (merahmati) orang yang mengulurkan kainnya (menyapu tanah) dengan sombong."22

Yang bermaksud: Diriwayatkan Anas (bin Malik) ra.: Ketika kami sedang duduk-duduk bersama Nabi saw di dalam sebuah masjid, datang seseorang yang mengenderai seekor unta. la menyuruh unta itu berlutut di halaman masjid, mengikat kaki depannya lalu bertanya, "Siapa di antara kalian yang bernama Muhammad?" Pada waktu itu Nabi saw sedang duduk di antara kami (para sahabatnya) dengan bersandar pada kedua tangannya. Kami menjawab, "Lelaki berkulit putih yang duduk bersandar dengan tangan-nya." Orang itu melihat ke arah Nabi saw, "Hai, anak ÑAbdul Muththalib."Nabi saw bersabda, "Aku ke sini untuk menjawab pertanyaan-pertanyaanmu." Orang itu bertanya kepda Nabi saw, "Aku ingin menanyakan sesuatu dan tampaknya akan sulit engkau jawab. Jadi jangan marah." Nabi saw bersabda, "Tanyakan apa pun yang ingin kau tanyakan." Orang itu berkata, "Aku bertanya dengan nama Tuhanmu, Tuhan orang-orang sebelummu, Apakah Allah mengutusmu sebagai Rasul untuk seluruh manusia?" Nabi saw menjawab, "Demi Allah, benar." Lebih jauh orang itu bertanya, "Dengan nama Allah aku bertanya. Apakah Allah menyuruhmu mendirikan shalat lima waktu dalam sehari semalam?" Nabi saw menjawab, "Demi Allah, benar." Orang itu kemudian bertanya, "Demi Allah! Apakah Allah memerintahkan kepadamu untuk berpuasa pada bulan Ramadhan?" Nabi saw menjawab, "Benar, demi Allah." Orang itu bertanya lagi, "Demi Allah! Apakah Allah menyuruhmu mengambil zakat dari orang-orang kaya untuk diberikan kepada orang-orang miskin?" Nabi saw menjawab, "Demi Allah, benar." Lalu orang itu berkata, "Aku beriman atas semua yang diturunkan (Allah) kepadamu, aku dikirim sukuku sebagai seorang utusan, namaku DhimÉm bin TsaÑlabah keluarga dari Bani SaÑd bin Bakar."23

Berdasarkan hadits di atas, keadaan Rasulullah saw semasa berada di kalangan para sahabatnya di dalam masjid dilihat tiada perbedaan yang menunjukkan beliau sebagai seorang insan penting yang diutuskan oleh Allah, sebaliknya dilihat semuanya setara. Penampilan Baginda saw yang sederhana tanpa pemakaian yang melambangkan keistimewaan serta Baginda saw yang duduk bersama dikelilingi oleh pengikut-pengikutnya tanpa berada di singgasana menunjukkan bahwa kesederhanaan adalah satu nilai penting dalam setiap aspek kehidupan, begitu juga dengan pembangunan sebuah masjid.

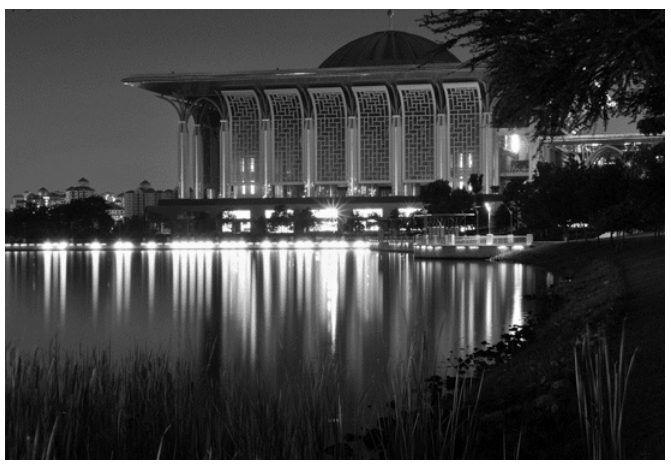

Gambar 8. Masjid Tuanku Mizan, Putrajaya (Sumber: www.google.com)

Dalam upaya menghindari kemubadziran dan mengamalkan kesederhanaan dalam pembangunan masjid, elemen-elemen yang bersifat perhiasan semata-mata tanpa adanya fungsi yang khusus perlu dihindari. Contohnya adalah elemen menara yang biasa terdapat di kebanyakan masjid di Malaysia seperti pada Masjid Tuanku Mizan (Gambar 8) secara khusus dan di seluruh dunia secara umumnya. Fungsi menara konon merupakan suatu tempat yang digunakan oleh muadzin untuk mengumandangkan adzan. Akan tetapi, pada zaman Rasulullah adzan dikumandangkan bukan di atas menara, namun di atas bumbung tertinggi di kawasan tersebut menurut KAC. Creswell ${ }^{24}$. Dengan kemodernan yang dimiliki oleh masyarakat hari ini, tidak diperlukan lagi penggunaan menara untuk mengumandangkan adzan karena telah digantikan oleh penggunaan pengeras suara. Oleh karena itu, penggunaan menara sebagai satu elemen dalam perancangan masjid tidaklah lagi bersesuaian menurut Oleg Grabar. Namun begitu, menurut Mohamad Tajuddin menara dapat dilihat 
sebagai penanda untuk menyatakan keberadaan masjid di suatu tempat ${ }^{25}$.

Sementara itu, asal usul azan dikumandangkan adalah untuk menyampaikan seruan agar shalat dilaksanakan pada waktu tersebut, yaitu untuk menandakan masuknya waktu shalat. Awal mulanya adzan adalah seperti yang dinyatakan oleh hadits berikut:

Yang bermaksud: Diriwayatkan dari Ibn Umar ra.: Ketika orang-orang Muslim tiba di Madinah, mereka berkumpul untuk mengerjakan shalat, dan menggunakan perhitungan waktu untuk melaksanakannya. Pada waktu itu adzan sebagai panggilan untuk mengerjakan shalat belum lagi diperkenalkan. Pada suatu hari mereke mendiskusikan masalah ini. Sebagian orang mengusulkan menggunakan loceng, sebagaimana dilakukan umat Kristiani, sebagian lain mengusulkan menggunakan terompet mirip tanduk, seperti digunakan umat Yahudi. Adalah Umar yang pertama kali mengusulkan dengan memanggil (orang-orang) untuk mengerjakan shalat, maka Rasulullah saw memerintahkan Bilal berdiri dan mengumandangkan adzan (sebagai panggilan kepada orang-orang untuk mengerjakan shalat). ${ }^{26}$

Dalam pembangunan masjid juga diperlukan bahasa arsitektural yang sesuai untuk menarik minat orang ramai untuk memakmurkannya. Hal ini dianggap memerlukan perhatian, misalnya pada perancangan pagar dan citra keseluruhan masjid tersebut. Reka bentuk pagar perlu memberi maksud ke arah menerima orang banyak atau masyarakat untuk memasuki perkarangan masjid. Hal ini dapat dilakukan dengan penggunaan pagar yang rendah ataupun sekedar memisahkannya dengan pohon-pohon yang tertentu beserta lansekap yang menarik seperti pada Masjid Kamping Air Mati, Perak (Gambar 9).

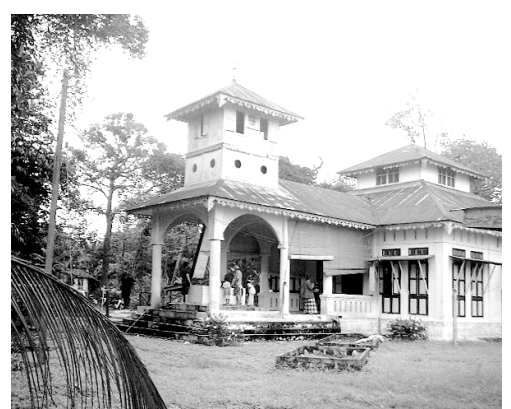

Gambar 9. Masjid Kampong Air Mati, Perak (Sumber: www.google.com)

Berbeda dengan kebanyakan masjid di negara ini seperti contoh pada Masjid Kampung Pasir Puteh (Gambar 10) yang mempunyai pagar yang tinggi dan menimbulkan keengganan kepada masyarakat untuk mendekatinya. Hal ini perlu dielak dan sewajarnya diambil pelajaran dari hadits Rasulullah saw dimana masjid pada zamannya tidak memiliki pagar dan memberi kebebasan untuk orang ramai keluar dan masuk pada setiap masa tanpa melihat status, kedudukan, dan usia. Hadits tersebut adalah seperti berikut:
Yang bermaksud: Diriwayatkan dari Ibn 'Abbas ra.: Pada suatu hari aku datang dengan menunggang seekor keledai betina, ketika itu aku telah mulai menginjak dewasa. Rasulullah saw tengah mengerjakan shalat di Mina. Tak ada dinding di hadapannya dan aku lewat di depan barisan beberapa orang tengah melakukan shalat. Aku membiarkan keledai lepas dan menerobos ke dalam barisan itu dan tidak ada seorang pun yang keberatan. $^{27}$

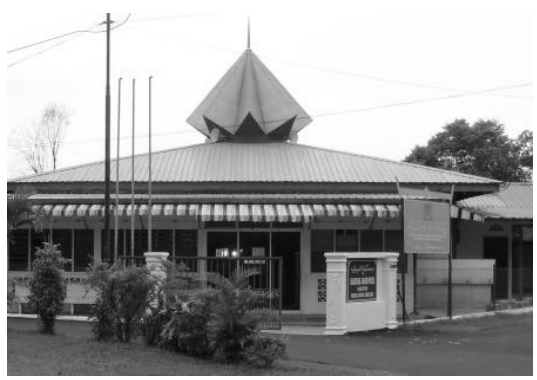

Gambar 10. Masjid Kampung Pasir Puteh (Sumber: www.google.com)

Sebagai sebuah agama yang sempurna merangkum semua aspek kehidupan penganutnya, ia bersifat mudah dalam kebanyakan aspeknya. Begitu juga dengan pembangunan masjid di mana Islam tidak gemar menyulitkan penganutnya seperti memerlukan kendaraan bermotor untuk ke masjid karena kedudukannya yang jauh. Apa yang hendak ditegaskan di sini ialah kebanyakan daripada perkara-perkara yang bersifat rumit dalam kehidupan manusia itu bermula dari diri manusia itu sendiri yang gemar menciptakan keperluan tersebut. Kesukaran dalam beribadah atau melakukan sesuatu aktivitas menyebabkan manusia melarikan diri dari perkara tersebut seperti yang dinyatakan di dalam hadits berikut:

Yang bermaksud: Diriwayatkan dari Anas ra.: Nabi Muhammad saw pernah bersabda, "Ringankanlah orang-orang (dalam masalah-masalah agama), dan janganlah membuatnya menjadi sukar bagi mereka dan berilah mereka kabar gembira dan janganlah membuatkan mereka melarikan diri (dari Islam)."28

Berdasarkan hadits di atas didapati bahwa kesulitan manusia dalam melakukan sesuatu dapat menyebabkan mereka menjauhi perkara tersebut. Sehubungan dengan itu, dapat disimpulkan bahwa kedudukan masjid perlu dipertimbangkan agar tidak menyulitkan orang banyak untuk datang berkunjung.

\section{Kedudukan dan lokasi}

Dalam isu kedudukan dan lokasi masjid ini dapat dilihat kebanyakan masjid di Malaysia kurang menitikberatkan persoalan ini terutama di kawasankawasan perkotaan, serta tidak ketinggalan juga di kawasan pedalaman seperti pada Masjid Kristal, Pulau Wan Man, Terengganu (Gambar 11). Sewajarnya kedudukan masjid berada di kawasan lingkungan pemukiman masyarakat dan tidak terpencil dari kawasan sekitarnya untuk menggalakkan penggunaan masjid dalam setiap aktivitas yang bukan saja 
berunsur religius, namun juga pelbagai kegiatan kemasyarakatan yang diperlukan pada masa kini. Pada zaman Rasulullah saw, masjid tidak pernah dibangun di tempat yang sukar untuk dikunjungi dan terpencil seperti yang dinyatakan di dalam hadits berikut:

Yang bermaksud: Diriwayatkan dari Abdullah bin Umar: "Sesungguhnya Rasulullah saw pernah singgah di Dzulhulaifah ketika umrah. Ketika haji pun beliau singgah di bawah pohon Samurah di sekitar tempat masjid yang berada di Dzulhulaifah. Apabila kembali dari peperangan, haji, atau umrah, beliau menuruni lembah yang berada di jalan itu. Apabila telah sampai di lembah itu, beliau menurunkan untanya di saluran air sungai yang berada di pinggir lembah bagian timur, kemudian beristirahat di tempat itu hingga waktu subuh." Di tempat itu, tidak ada masjid yang dibangun dari batu dan tidak ada pula masjid yang berdiri di atas bukit. Di sana ada sebidang tanah yang menjorok ke sungai yang dipakai shalat oleh Ibnu Umar, di lembahnya terdapat tumpukan pasir. Rasulullah saw pernah shalat di tempat tersebut. Tiba-tiba tumpukan pasir itu terbawa hanyut oleh air sungai tersebut, hingga tempat yang dipakai shalat oleh Ibnu Umar tertimbun air. ${ }^{29}$

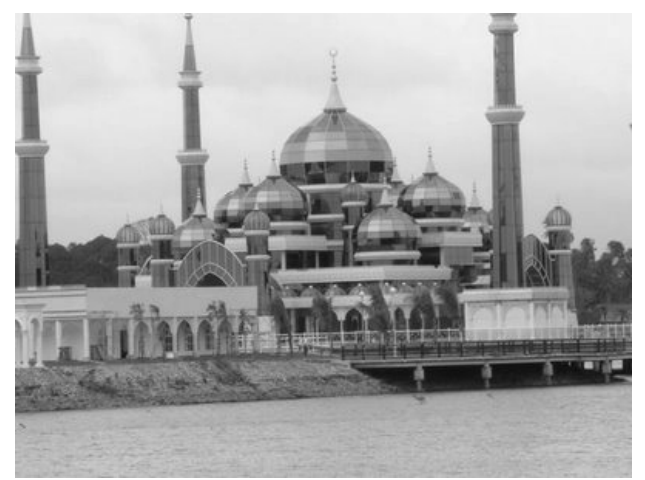

Gambar 11. Masjid Kristal, Pulau Wan Man, Terengganu (Sumber: www.google.com)

Dari hadits di atas dapat dipahami bahwa pada zaman Rasulullah saw, masjid tidak dibangun di tempat-tempat terpencil yang menyukarkan orang banyak untuk berkunjung, meskipun kedudukan tersebut mempunyai sumber air yang sangat diperlukan oleh musafir dan juga hewan ternak. Kedudukan dan lokasi masjid sangat dititikberatkan sejak zaman Rasulullah saw dan beliau bersama para sahabatnya akan berusaha untuk mendapatkan lokasi-lokasi yang terbaik dan bersesuaian bagi pembangunan masjid dan tidak akan ragu-ragu untuk mengorbankan sesuatu yang merupakan hak milik mereka dan sebaliknya seperti hadits berikut dimana mereka telah menggali kubur-kubur orang Musyrik, meratakan tanah dan menebang pohon-pohon kurma untuk menyediakan tapak masjid tersebut:

Yang bermaksud: Diriwayatkan dari Anas r.a.: Ketika Nabi Muhammad saw tiba di Madinah, Nabi Muhammad saw turun dari untanya di bagian atas kota Madinah di tengah-tengah suku yang disebut Bani Amr bin Auf. Nabi saw tinggal di sana selama empat belas malam. Kemudian suku An-Najjar dikirim (untuk mengawal)
Nabi saw dan mereka datang dengan bersenjatakan pedang-pedang mereka. Seakan-akan (baru saja) aku melihat Nabi saw duduk di atas rahilah (unta) beriringan dengan Abu Bakar yang berada di belakangnya dan semua (anggota) suku an-Najjar mengelilingi Nabi saw hingga Nabi saw turun di halaman rumah Abu Ayub. Nabi Muhammad sangat mencintai shalat dan kapan pun waktu shalat tiba Nabi saw segera mengerjakannya, bahkan di kandang domba. Di kemudian hari Nabi saw meme-rintahkan untuk membangun sebuah masjid dan menemui sebahagian orang-orang suku An-Najjar dan berkata kepada mereka, "Wahai suku Najjar! Berapa harga tanahmu ini?" Mereka menjawab, “Tidak! Demi Allah! Kami tidak mengharapkan imbalan untuk tanah ini kecuali dari Allah swt." Anas menambahkan: Di sana terdapat kuburan orang-orang musyrik, sebagian tanah tidak rata, dan terdapat pohon-pohon kurma. Nabi memerintahkan membongkar kuburan orangorang musyrik itu dan meratakan sebagian tanah yang tidak rata dan menebang pohon-pohon kurma. (Kami semua mengerjakan apa yang diperintahkan Nabi saw). Mereka menggunakan batang-batang pohon kurma yang telah ditebang untuk kiblat masjid (sebagai dinding) dan mereka menggunakan dua buah batu sebagai dinding samping (masjid). Para sahabat Nabi saw membawa batu-batu itu sambil membaca beberapa baris puisi (syair). Nabi saw ikut bekerja bersama mereka dan berkata, "Tak ada kebaikan selain hari kiamat-Mu ya Allah! Maka berilah maaf kaum Anshar (orang-orang yang menolong) dan kaum Muhajir (orang-orang yang berhijrah)." 30

Hadits di atas menceritakan usaha yang dilakukan oleh Nabi Muhammad saw bersama para sahabatnya untuk mendirikan Masjid Quba. Lokasi masjid tersebut dilihat sesuai oleh Baginda saw setelah berada di tempat tersebut selama dua minggu, meskipun tapak tersebut adalah pekuburan lama. Namun begitu niat Baginda diteruskan karena dilihat lokasinya sesuai dengan kebutuhan masyarakat Muslim saat itu.

\section{Berdekatan dengan pemukiman dan kegiatan penduduk}

Kedudukan masjid yang dianjurkan adalah yang dekat dengan kediaman dan pemukiman penduduk di kawasan tersebut. Hal ini untuk memudahkan orang banyak untuk berkunjung ke masjid terutama pada waktu shalat lima waktu serta untuk pelbagai kegiatan lain yang diperlukan. Apabila suara adzan yang berkumandang mengajak penduduk untuk menunaikan shalat terdengar di kawasan kediaman memberi kesadaran kepada mereka agar menyegerakan tuntutan shalat itu dengan menunaikannya di masjid. Adalah menjadi kewajiban juga bagi seorang Muslim yang mendengar adzan dari kediaman atau tempat manapun dia berada untuk berkunjung ke masjid dan berjamaah menunaikan panggilan shalat tersebut tanpa melihat keudzuran yang dialami selagi ia berkemampuan sebagaimana yang dijelaskan di dalam hadits yang disebutkan di bagian awal tulisan $\mathrm{ini}^{31}$.

Jarak yang dekat antara masjid dengan pemukiman dan pelbagai aktivitas harian masyarakat ini memberi peluang kepada mereka untuk berkunjung 
dan berjamaah dalam menunaikan shalat tanpa perlu tergesa-gesa karena jaraknya yang jauh atau sukar untuk dikunjungi. Perbuatan tergesa-gesa semasa mengejar waktu shalat juga ditegur oleh Rasulullah saw seperti yang dinyatakan di dalam hadits berikut:

Yang bermaksud: Diriwayatkan dari Abu Qatadah ra.: Ketika kami sedang mengerjakan shalat bersama Rasulullah saw, beliau mendengar suara gaduh sebagian orang. Setelah shalat usai Nabi saw bersabda, "Apa yang terjadi?" Mereka menjawab, “Kami tergesa-gesa mengerjakan shalat." Nabi saw bersabda, "Janganlah mengerjakan shalat dengan terburu-buru, dan kapan pun kalian datang (terlambat) untuk mengerjakan shalat, maka datanglah dengan tenang, ikuti shalat (orang-orang) yang lebih dahulu (dari kalian) dan lengkapkan shalatmu yang tertinggal." ${ }^{32}$

Apabila masjid terletak di kawasan lingkungan yang menjadi pusat kegiatan masyarakat umpamanya perkantoran dan juga pemukiman akan mendorong mereka untuk berkunjung ke masjid untuk berjamaah. Oleh itu tidak perlu lagi keberadaan musholamushola kecil yang tidak nyaman dan sempit di bangunan-bangunan perniagaan dan perkantoran. Hal ini dikarenakan telah disebutkan oleh Rasulullah saw akan kelebihan menunaikan shalat di masjid berjamaah dibandingkan secara perseorangan di rumah atau mushola di pusat perniagaan, kantor, dan sebagainya, seperti yang telah dinyatakan di dalam hadits berikut:

Yang bermaksud: Diriwayatkan dari Abu Hurairah ra.: Nabi Muhammad saw pernah bersabda, "Mengerjakan shalat berjamaah (berpahala) dua puluh lima kali lipat dibandingkan mengerjakan shalat sendiri di dalam rumah atau mengerjakan shalat di pusat perdagangan (pusat perbelanjaan), karena jika seseorang berwudhuk dengan sempurna kemudian pergi menuju masjid dengan niat mengerjakan shalat, untuk setiap langkah yang diayunkan dalam perjalanannya ke masjid, Allah akan memberinya pahala dan memaafkan dosanya hingga ia masuk ke dalam masjid. Ketika ia sudah berada di dalam masjid ia mengerjakan shalat dan pada saat ia duduk menunggu untuk mengerjakan shalat (berjamaah), para malaikat akan memohonkan keampunan Allah dan mereka (para malaikat) berkata, "Ya Allah! Kasihilah ia. Ampunilah ia." Selama ia menunggu mengerjakan shalatnya dan (selama ia) tidak berhadats." 33

Bagi masjid yang terletak berdekatan dengan pusat perniagaan, perkantoran, dan juga pasar pasti menjadi pusat untuk menunaikan shalat dan juga pelbagai aktivitas lain yang diperlukan oleh masyarakat modern pada hari ini dalam urusan keseharian, demikian saran Mohd. Tajuddin ${ }^{34}$. Untuk keperluan tersebut maka perlu diwujudkan pelbagai kemudahan yang mampu menarik masyarakat menjadikan masjid sebagai lokasi utama semasa waktu shalat. Begitu juga pada zaman Rasulullah di mana terdapat masjid di sekitar pasar-pasar dan pusat perniagaan yang menjadi tumpuan masyarakat seperti yang dinyatakan di dalam hadits berikut:

Yang bermaksud: Diriwayatkan dari Anas bin Malik ra.: Ketika Nabi saw bersama para sahabat beliau berada di Zaura' (sebuah tempat di Madinah dekat pasar dan masjid), beliau meminta satu gelas air. Lalu beliau meletakkan telapak tangannya ke dalamnya, maka memancarlah air dari celah jemari beliau sehingga semua sahabat berwudhu (dengannya). Kata Qatadah (perawi hadits ini), "Aku bertanya kepada Anas, 'Berapa orang yang berwudhu saat itu wahai Abu Hamzah (Anas bin Malik)?"” Jawabnya, “Mereka kurang lebih berjumlah tiga ratus orang." ${ }^{35}$

Hadits di atas menceritakan peristiwa yang menonjolkan kemukjizatan Nabi Muhammad saw, dengan latar belakang tempat berupa sebuah masjid yang berdekatan dengan pasar. Didapati masjid yang dibangun berdekatan dengan pasar pada zaman itu untuk memudahkan urusan ibadah para pengunjung dan juga penjual di pasar tersebut. Kedudukan masjid yang berdekatan dengan pasar, pusat perniagaan, dan pemukiman memerlukan banyak pintu masuk untuk memudahkan pergerakan orang banyak untuk masuk dari setiap arah. Saran bagi ukuran jalan umum mengikuti hadits ${ }^{36}$ adalah seperti berikut:

Yang bermaksud: Diriwayatkan dari Abu Hurairah ra.: Nabi saw bersabda, "Apabila kalian bersengketa tentang jalan, perlebarlah jalan itu tujuh hasta." 37

Ukuran tujuh hasta adalah hampir sama dengan sepuluh kaki setengah. Lebar tersebut direncanakan sekiranya berlaku pertengkaran terhadap jalur yang digunakan oleh orang umum, namun tidak dinyatakan secara jelas untuk pemukiman atau masjid.

\section{Pengkhususan dan perancangan ruang}

Bagian ini memaparkan hadits-hadits yang menceritakan pelbagai aktivitas yang terdapat di dalam dan perkarangan masjid serta kemungkinan ruangruang khusus yang diperlukan untuk pelbagai aktivitas. Di antara aktivitas-aktivitas tersebut ialah berniaga, ruang perawatan untuk orang sakit, beriadah dan mentalaah.

Di antara ruang-ruang yang dilihat sesuai untuk disediakan di masjid ialah kedai-kedai sederhana untuk disewakan kepada pedagang-pedagang yang berminat untuk menjalankan perniagaannya di dalam kawasan masjid. Jenis perniagaan tersebut hendaklah berunsurkan keperluan asas masyarakat Muslim seperti alat bersuci, kelengkapan pakaian shalat, alQur'an, dan sebagainya. Selain itu diperlukan juga kedai yang menjual bahan makanan seperti warung makan dan sebagainya. Selain itu juga bisa diwujudkan pelbagai keperluan masyarakat modern pada hari ini seperti bank, pejabat pos, konter tiket, dan sebagainya. Pada zaman Rasulullah saw turut tidak ketinggalan dengan kegiatan perniagaan di pekarangan masjid seperti yang dinyatakan di dalam hadits berikut:

Yang bermaksud: Diriwayatkan (dari Abdullah bin Umar): Umar bin Al-Khattab ra. melihat jubah (jas panjang) sutra (dijual) di depan pintu masjid dan berkata kepada Rasulullah saw, "Aku ingin Anda membeli pakaian ini untuk dikenakan pada hari 
Jumaat dan ketika menerima para duta yang menemui Anda." Rasulullah saw menjawab, "Pakaian ini hanya dikenakan oleh orang yang tidak memperoleh bagian (pahala) di hari kiamat." Di kemudian hari pakaian-pakaian serupa dihadiahkan kepada Rasulullah saw dan Nabi saw memberikan salah satunya kepada Umar bin Al-Khattab yang berkata, "Ya Rasulullah! Kau memberikan pakaian ini kepadaku meskipun pakaian Utharid (pakaian seorang saudagar yang menjual pakaian sutra di depan pintu masjid) padahal kau pernah menegurku untuk tidak mengenakan pakaian itu." Rasulullah saw menjawab, "Aku memberikannya kepadamu bukan untuk dipakai olehmu." Dan Umar pun memberikan itu kepada saudara laki-lakinya yang Musyrik di Makkah untuk dipakai olehnya. ${ }^{38}$

Selain aktivitas perniagaan yang diwujudkan di sekitar masjid tersebut, perlu juga diadakan klinik perawatan untuk wanita, orang sakit, dan anakanak. Keberadaan klinik tersebut secara tidak langsung memberi kesadaran akan kesehatan terhadap orang banyak. Pada zaman Rasulullah saw juga terdapat ruang untuk merawat orang cedera semasa peperangan seperti yang dinyatakan di dalam hadits berikut:

Yang bermaksud: Diriwayatkan dari Aisyah ra.: Pada suatu hari saat berlangsungnya Perang Khandaq (Perang Parit) arteri atau urat halus lengan Saad (bin Muadz) terluka dan Nabi Muhammad saw mendirikan tenda di dalam masjid untuk merawatnya. Di sana ada tenda lain milik suku Ghiffar dan darah mengalir dari tenda Saad ke arah tenda milik suku Ghaffar. Mereka berteriak, "Wahai pemilik tenda! Apa yang datang dari tenda anda ini?" Mereka melihat Saad mengalami pendarahan serius dan ia pun meninggal di dalam tenda itu. ${ }^{39}$

Bilik untuk memandikan jenazah juga perlu disediakan di masjid, kedudukannya hendaklah tidak jauh dari tempat mengambil wudhu agar orang banyak merasa sadar dan mengingat mati apabila memandang bilik tersebut. Jenazah juga dianjurkan untuk disembahyangkan di masjid untuk memberi peringatan kepada orang banyak dan juga keluarga almarhum. Terdapat juga hadits yang membicarakan perkara ini seperti berikut:

Yang bermaksud: "Diriwayatkan dari Aisyah ra.: Sewaktu Saad bin Abi Waqash ra. wafat, istri-istri Nabi saw mengutus agar jenazah Saad bin Abi Waqash ini dibawa ke masjid (Nabawi) agar mereka dapat menshalatkannya juga, lalu sahabat-sahabat melaksanakannya. Jenazah Saad lalu diletakkan di dekat kamar mereka, lalu dishalatkannya. Jenazah itu dibawa keluar melalui pintu jenazah menuju tempattempat duduk. Kemudian sampailah berita kepada mereka bahwa orang-orang mencela perbuatan yang demikian ini. Mereka berkata bahwa tidak sepantasnya jenazah dimasukkan ke dalam masjid. Hal ini didengar oleh Aisyah, maka dia berkata, "Cepat sekali orang-orang ini mencela hal yang yang tidak mereka ketahui? Mereka mencela kami karena memasukkan jenazah ke dalam masjid, padahal Rasulullah saw menshalatkan Suhail bin Baidha di dalam masjid." 40

Hadits di atas menceritakan peristiwa dimana istri-istri Rasulullah saw meminta untuk melakukan shalat jenazah atas Saad bin Abi Waqqash di dalam masjid Baginda tetapi dicela oleh setengah pihak. Dari peristiwa tersebut dapat diambil pelajaran akan kedudukan bilik jenazah yang sesuai dengan ruang shalat wanita. Kedudukan bilik jenazah tersebut tidak melalui ruang yang sama ke ruang shalat wanita, sebaliknya tempat sembahyang jenazah terletak berdekatan dengan ruang shalat wanita.

\section{Jemaah dan pengguna}

Fungsi utama bagi sebuah masjid pada zaman Rasulullah saw bukan saja sebagai tempat beribadah, tetapi turut dijadikan sebagai pusat untuk menuntut ilmu, penyampaian ilmu agama, perbincangan isu-isu terkini, serta perancangan peperangan. Karena itu, pelbagai jenis aktivitas dapat dilihat berdasarkan fungsi-fungsi masjid tersebut serta pelbagai lapisan masyarakat yang terlibat termasuk golongan yang berketerbatasan fisik, orang tua, remaja, anak-anak, lelaki, wanita, dan sebagainya. Sehubungan dengan itu, perancangan sebuah masjid dilihat sewajarnya memberi kenyamanan dan memenuhi keperluan semua lapisan masyarakat tersebut tanpa diskriminasi dalam soal umur, kedudukan, dan juga kesehatan.

Perkara ini perlu dipertimbangkan karena masyarakat kita terdiri dari pelbagai jenis lapisan masyarakat yaitu lelaki dewasa, remaja, golongan tua, orang dengan keterbatasan fisik, anak-anak, wanita, musafir, dan sebagainya. Hal ini dapat dilihat dari hadits Baginda Rasulullah saw yang memberikan tuntunan bagi seseorang untuk ke masjid apabila terdengar adzan dari tempat tinggalnya meskipun dia seorang yang buta seperti hadits yang telah dinyatakan sebelum ini. Sehubungan dengan hal itu, keperluan kekhususan bagi golongan ini di dalam masjid tersebut seperti kamar kecil yang khusus, atau jalur-jalur sirkulasi yang tidak menyukarkan pergerakannya seperti keberadaan anak tangga yang banyak untuk bergerak dari satu ruang ke ruang yang lainnya.

Golongan kedua yang perlu dipertimbangkan dari segi keperluan mereka di masjid adalah remaja. Remaja merupakan golongan pertengahan di antara anak-anak dan dewasa yang senantiasa aktif, ingin tahu, dan agresif. Oleh karena itu, perhatian dan didikan yang sempurna perlu diterapkan dalam diri mereka dengan mendorong agar mereka akrab dengan masjid. Golongan ini juga merupakan calon generasi akan datang dalam membentuk sebuah masyarakat yang Islami melalui masjid sebagai institusi yang mengantarkan kepada misi tersebut. Kegemaran mereka kepada aktivitas yang dinamis dapat dijadikan satu daya tarik bagi golongan ini ke masjid. Ketersediaan ruang dan kemudahan bagi aktivitas mereka secara tidak langsung menarik minat para remaja ini untuk memasuki pekarangan masjid serta menjadikan masjid sebagai tempat mengisi masa luang mereka. Apabila masjid hanya tertumpu kepada aktivitas kerohanian setiap saat, maka dapat 
menimbulkan kebosanan terutama bagi golongan remaja. Rasulullah saw juga memilih waktu-waktu tertentu untuk memberi peringatan dan nasihat kepada para sahabatnya untuk menghindarkan mereka dari kebosanan, seperti yang dinyatakan di dalam hadits berikut:

Yang bermaksud: Diriwayatkan dari Ibn Mas'ud ra.: Nabi Muhammad saw memilih waktu yang tepat untuk berkhutbah sehingga kami tidak merasa bosan. (Nabi saw tidak mengganggu kami dengan melibatkan kami dalam pembicaraan agama dan ilmu pengetahuan terus-menerus sepanjang waktu). ${ }^{41}$

Keberadaan aktivitas-aktivitas yang bersifat permainan di masjid juga terdapat pada zaman Rasulullah saw seperti yang dinyatakan di dalam hadits-hadits berikut:

Yang bermaksud: Diriwayatkan dari Aisyah ra.: Rasulullah saw pernah memasuki rumah saya, sedangkan di dekat saya ada dua orang budak perempuan yang sedang menyanyikan lagu Bu'ats. Lalu beliau berbaring di atas tikar sambil memalingkan wajah. Tiba-tiba, Abu Bakar ra. masuk dan membentak saya sambil berkata, "Ada seruling setan di rumah Rasulullah saw?" Rasulullah saw menoleh kepadanya seraya bersabda, "Biarkanlah mereka berdua itu." Setelah beliau lengah, saya mengedipkan mata (memberi isyarat) kepada kedua budak perempuan itu, lalu mereka keluar. Pernah pada suatu hari raya, ketika orang-orang hitam sedang bermain dengan perisai dari kulit (perang-perangan), saya meminta izin Rasulullah saw untuk menontonnya, atau beliau bertanya, "Apakah engkau tertarik untuk menontonnya?" Saya menjawab, "Ya" Lalu beliau menempatkan saya untuk berdiri di belakang beliau. Pipi saya menempel pada pipi beliau, beliau bersabda, "Teruskan permainan kalian, wahai Bani Arfidah!” Setelah saya merasa bosan, beliau bertanya, "Apakah engkau sudah merasa bosan?" saya menjawab, "Ya." Beliau bersabda, "Pergilah!"42

Yang bermaksud: Diriwayatkan dari Aisyah ra.: Pada suatu hari aku melihat Rasulullah saw di depan pintu rumahku ketika pada waktu yang bersamaan orangorang Ethiopia bermain-main di dalam masjid (memamerkan keahlian mereka melempar tombak). Rasulullah saw menyelubungiku dengan rida-nya (kain penutup bagian atas tubuh) sehingga aku dapat menyaksikan permainan mereka. Di dalam kutipan yang lain disebutkan, "Bermain-main dengan tombak mereka." 43

Keberadaan pelbagai kemudahan berunsur hiburan bukan saja akan menarik golongan remaja tetapi juga mendorong mereka yang telah berkeluarga untuk turut serta meluangkan waktu bersama anakanak mereka. Penyediaan area permainan kanakkanak yang sederhana juga wajar disediakan karena golongan ini juga memerlukan ruang khusus untuk pelbagai aktivitas mereka di masjid tersebut. Kanakkanak perlu digalakkan untuk ke masjid untuk memupuk rasa cinta mereka terhadap masjid seperti yang dilakukan oleh Rasulullah saw seperti yang dinyatakan di dalam hadits-hadits berikut:

Yang bermaksud: Diriwayatkan dari Abu Qatadah AlAnshari ra.: Rasulullah saw pernah mengerjakan shalat sambil menggendong Umamah, anak perempuan Zainab ra. (putri Nabi saw) dengan Abu Al-
'Ash bin Rabi' bin ;Abdusy-Syams. Ketika Nabi saw sujud, Nabi saw menurunkan Umamah dari gendongannya, dan ketika Nabi saw berdiri, Nabi saw menggendongnya. ${ }^{44}$

Yang bermaksud: Diriwayatkan dari Mahmud bin Rabi' ra.: Ketika umurku lima tahun, aku ingat, Nabi Muhammad saw mengambil air dari ember (yang biasa digunakan mengambil air dari sebuah sumur) dengan mulutnya dan menyemburkannya ke wajahku. ${ }^{45}$

Kehadiran anak-anak di masjid biasanya sering kali ditemani oleh ibunya. Karena itu para wanita juga memerlukan ruang-ruang tertentu untuk menjalankan aktivitas mereka dengan anak-anak di sampingnya. Rasulullah turut mempertimbangkan keberadaan wanita dan anak-anak yang datang ke masjid, seperti yang dinyatakan di dalam hadits berikut:

Yang bermaksud: Diriwayatkan dari Abu Qatadah ra.: Nabi Muhammad saw pernah bersabda, "Ketika aku berdiri untuk mengerjakan shalat, aku berniat untuk memperpenjangkannya tetapi ketika aku mendengar tangis seorang anak, aku memperpendeknya, aku tidak mau merepotkan ibu anak itu." 46

Kehadiran wanita-wanita ke masjid sepatutnya bukan saja semasa menunaikan shalat tarawih ataupun untuk menunaikan solat sunat hari raya. Sebaliknya, kaum wanita perlu juga diajak untuk melaksanakan shalat fardhu dengan diiringi pasangan dan anak-anak. Kedatangan wanita ke masjid tidak pernah dihalang oleh Rasulullah saw selagi mereka tidak melakukan perkara yang dilarang, bahkan Rasulullah saw turut memperuntukkan satu hari khusus untuk golongan wanita bersama Baginda untuk menyampaikan peringatan dan teladan seperti yang dinyatakan di dalam hadits-hadits berikut:

Yang bermaksud: Diriwayatkan dari Abu Sa'id Al-Khudri ra.: Beberapa orang perempuan memohon kepada Nabi Muhammad saw untuk memberi mereka waktu secara terpisah selama sehari sebab kaum pria telah mengambil seluruh waktunya. Mendengar permintaan itu Nabi Muhammad saw menjanjikan kepada mereka satu hari untuk memberikan pelajaran dan perintahperintah agama. Pada hari yang dijanjikan Rasulullah saw bersabda, "Seorang perempuan yang melahirkan tiga orang anak yang meninggal akan dilindungi mereka dari api neraka." Seorang perempuan bertanya, "Bagaimana kalau dua?" Nabi Muhammad saw menjawab, "la pun akan dilindungi dari api neraka." 47

Yang bermaksud: Diriwayatkan dari Ibnu Umar ra.: Nabi Muhammad saw bersabda, "Jika istri-istrimu meminta izin untuk pergi ke masjid pada malam hari, beri mereka izin." ${ }^{48}$

Yang bermaksud: Diriwayatkan dari Zainab AlTsaqafiyyah ra.: Rasulullah saw pernah bersabda kepada kami , "Apabila salah seorang daripada kamu pergi ke masjid (wahai kaum wanita), janganlah memakai wewangian." 49

Yang bermaksud: Diriwayatkan dari Ummu Atiyah ra.: Aku mendengar dari Rasulullah saw bahwa gadis-gadis perawan yang belum kawin, perempuan-perempuan dewasa, dan kaum perempuan yang sedang haic hendaknya keluar dan ikut serta melakukan perbuatan- 
perbuatan baik sebaik keyakinan orang-orang yang beriman, tetapi orang-orang yang sedang haid harus menjauh dari tempat shalat. Sesorang bertanya (kepada Ummu Athiyah) (dengan terkejut), "Apakah anda bilang kaum perempuan yang sedang haid?" la menjawab, "Bukankah perempuan yang sedang haid hadir (di) Arafah dan mengerjakan berbagai perbuatan baik?" 50

Terdapat juga kehadiran para wanita dan keluarga ke masjid sebagai musafir untuk beristirahat. Sehubungan dengan itu, adalah wajar disediakan ruang-ruang yang bersifat privat untuk beristirahat dan disewakan bagi keluarga musafir tersebut. Pada zaman Rasulullah saw, masjid juga menjadi tempat perlindungan bagi seorang budak perempuan, budak tersebut telah mendirikan kemahnya di dalam masjid seperti yang dinyatakan di dalam hadits tersebut:

Yang bermaksud: Diriwayatkan dari Aisyah ra: Ada seorang budak perempuan berkulit hitam milik sebuah suku Arab dan mereka memerdekakan budak perempuan itu tetapi ia tetap tinggal bersama mereka. Pada suatu hari salah seorang gadis dari suku mereka datang dengan mengenakan selendang kulit berwarna merah berhias batu-batu mulia. Batu itu jatuh, atau ia menyimpannya entah di mana. Seekor burung walet lewat, melihatnya tergeletek dan menyangkanya sebagai sekerat daging lalu membawanya terbang. Orang-orang mencari batu mulia itu namun tidak berhasil menemukannya. Mereka pun menuduhku mencurinya dan menggeledah tubuhku bahkan menggeledah bagian tubuhku yang terlarang." Lebih jauh budak perempuan itu berkata, "Demi Allah! Ketika aku berdiri dalam keadaan (teraniaya) itu, burung walet yang sama merenggutkan selendang merah si gadis lewat dan menjatuhkannya di depan mereka. Aku berkata kepada mereka, 'Inilah yang kau tuduhkan padaku, sesungguhnya aku tidak bersalah.'”

(Aisyah ra.) menambahkan: Budak perempuan itu menemui Rasulullah saw dan memeluk Islam. Ia memiliki sebuah kemah atau sebuah kamar kecil di dalam masjid. Kapan pun ia memanggilku, ia akan berbicara denganku dan kapan pun ia duduk bersamaku, ia akan mengatakan hal ini: "Kasus selendang itu, satu dari sekian keajaiban Tuhanku. Sungguh ia telah menyelamatkan aku dari orang-orang kafir itu." Aisyah menambahkan: Sekali waktu aku bertanya kepadanya, "Apa yang (sesungguhnya yang pernah) terjadi padamu? Setiap kali kau duduk bersamaku, kau selalu mengucapkan syair itu." (Mendengar pertanyaanku) ia pun menceritakan seluruh kemalangan yang telah menimpanya itu. ${ }^{51}$

Demikian pula bagi golongan lelaki dewasa, kedatangan mereka ke masjid selain menunaikan shalat adalah untuk aktivitas kerohanian lain seperti mendengarkan ceramah, membaca buku, belajar ilmu Tajwid dan al-Qur'an, bermusyawarah, dan sebagainya. Ruang musyawarah diperlukan di masjid untuk membicarakan permasalahan dan penyelenggaraan masjid, serta sebagai tempat imam berbincang dan memberikan nasehat atau konsultasi bagi mereka yang memerlukannya. Situasi ini juga terdapat pada zaman Rasulullah saw, dimana perlunya ruang yang privat untuk membincangkan sesuatu terdapat di dalam hadits berikut:
Yang bermaksud: Diriwayatkan dari (Anas bin Malik) ra.: Ketika Allah memberikan Rasul-Nya harta kekayaan suku Hawazin sebagai faai (rampasan perang), Nabi saw memberi sejumlah orang Quraisy seratus unta lebih. Melihat hal itu sejumlah orang Anshar berkata kepada Rasulullah saw, "Semoga Allah mengampuni Rasul-Nya! la memberi sedemikian banyak kepada orang Quraisy dan meninggalkan kita, padahal pedang-pedang kami masih basah dengan darah mereka (orang-orang kafir)." Kata Anas, ketika persoalan itu diberitahukan kepadanya, Rasulullah saw memanggil orang-orang Anshar berkumpul di sebuah tenda kulit. Orang lain (selain suku Anshar) tidak diperbolehkan masuk. Setelah semuanya berkumpul, Rasulullah saw bersabda kepada mereka, "Apakah perkataan yang telah kalian ucapkan perihalku?" Orang-orang terpelajar dari kalangan mereka menjawab. "Ya Rasulullah! Orangorang bijak di antara kami tidak mengatakan apa pun." 52

Dari hadits di atas dapat dilihat bagaimana cara Rasulullah saw menyampaikan sesuatu yang sulit dan rahasia kepada golongan Anshar dengan memanggil mereka ke tempat yang terlindung dari pendengaran orang banyak. Oleh karena itu, wajar sekiranya disediakan ruang khusus untuk aktivitas-aktivitas tertentu seperti konsultasi, diskusi, musyawarah, dan sebagainya.

\section{Permasalahan Keselamatan dan Kawasan Pribadi Masjid}

Bagian ini menjelaskan permasalahan yang berkaitan dengan keselamatan dan kawasan pribadi masjid. Perbincangan ini terbagi dua, yaitu permasalahan keselamatan harta benda masjid dan isu penggunaan pagar. Keselamatan dan ruang pribadi merupakan perkara penting dalam setiap lapisan masyarakat bergantung kepada aktivitas yang dilakukan dan juga tempat. Dalam masalah keselamatan dan ruang pribadi di masjid terutama bagi golongan wanita, diperlukan perhatian yang cukup sebagaimana Rasulullah saw sangat benci apabila ruang pribadinya diganggu, seperti diintip, dimasuki tanpa ijin, dan sebagainya, sebagaimana dinyatakan di dalam hadits berikut:

Yang bermaksud: "Sahl bin as-Sa'idi ra. berkata: “Ada seseorang mengintai dari lubang di pintu rumah Rasulullah saw sedang di tangan Rasulullah saw ada sisir besi digunakan untuk menggaruk kepalanya, dan ketika Nabi saw melihatnya lalu Baginda bersabda: "Kalau aku mengetahui bahwa anda mengintai aku, pasti aku cucukkan besi ini di kedua matamu." Nabi saw bersabda lagi: "Sesungguhnya diadakan peraturan minta ijin hanya karena mata." 53

Hadis di atas menunjukkan betapa hinanya perbuatan tersebut sehingga Baginda tidak ragu untuk mencucuk kedua mata pengintai tersebut. Oleh karena itu, isu ini wajar dipertimbangkan dalam perancangan sebuah masjid.

Dalam isu penggunaan pagar untuk memelihara keselamatan harta benda masjid dilihat tidak begitu praktis untuk digunakan karena dapat menimbulkan rasa enggan dari masyarakat untuk mendekati kawasan tersebut. Sebaliknya, jika hanya dipisahkan oleh 
lansekap atau tumbuhan maka dapat memberi kesan menerima kehadiran orang banyak tanpa melihat derajat, keturunan, dan usia.

"Diriwayatkan dari Ibn Abbas ra.: Pada suatu hari aku datang dengan menunggang seekor keledai betina, ketika itu aku telah mulai menginjak dewasa. Rasulullah saw tengah mengerjakan shalat di Mina. Tak ada dinding di hadapannya dan aku lewat di depan barisan beberapa orang tengah melakukan shalat. Aku membiarkan keledai lepas dan menerobos ke dalam barisan itu dan tidak ada seorang pun yang keberatan." 54

Hadits di atas juga dapat diinterpretasikan salah satu upaya untuk menarik kedatangan orang ramai adalah dengan tidak mewujudkan pagar yang bersifat pemisah. Ini karena Rasulullah saw tidak pernah membuat sembarang pagar atau melarang apa saja yang masuk ke dalam masjidnya, sekalipun seekor keledai seperti maksud hadits di atas.

\section{Ekonomi dan Pengurusan}

Bagian ini membicarakan tentang ekonomi masjid dan pengurusannya, yaitu dalam hal pengurusan keuangan. Didapati kebanyakan masjid pada hari tidak mempunyai sumber keuangan yang mandiri untuk penyelenggaraan aktivitas masjid, dan sebagainya. Masjid sewajarnya mempunyai sumber keuangannya sendiri untuk kepentingan institusinya, serta mereka yang memerlukan, sebagaimana yang dapat dipelajari dalam hadits (Sahih Muslim, Vol. II, p. 48) berikut:

Mundhir b. Jarir reported on the authority of his father. While we were in the company of the Messenger of Allah (may peace be upon him) in the early hours of the morning, some people came there (who) were barefooted, naked, wearing striped woollen clothes, or cloaks, with their swords hung (around their necks). Most of them, nay, all of them, belonged to the tribe of Mudar. The colour of the face of the Messenger of Allah (may peace be upon him) underwent a change when he saw them in poverty. He then entered (his house) and came out and commanded Bilal (to pronounce Adhan). He pronounced Adhan and Iqama, and he (the Holy Prophet) observed prayer (along with his Companion) and then addressed (them reciting verses of the Holy Qur'an): "O people, fera your Lord, Who created you from a single being" to the end of the verse, "Allah is ever a Watcher over you" (iv.1). (He then recited) a verse of sura Hashr: "Fear Allah, and let every soul consider that which it sends forth for the morrow and fear Allah" (ix. 18). (Then the audience began to vie with one another in giving charity). Some donated a dinar, others a dirham, still others clothes, some donated a sa'of wheat, some a sa' of dates; till he (the Holy Prophet) said: (Bring) even if it is half a date. Then a person from among the Ansar came therewith a money bag which his hands could scarcely loft; in fact, they could not (lift). Then the people followed continuously, till I saw two heaps of eatables and clothes, and I saw the face of the Messenger (May peace be upon him) glistening like gold (on account of joy). The Messenger of Allah (May peace be upon him) said: He who sets a good precedent in Islam, there is a reward for him for this (act of goodness) and reward of that also who acted according to subsequently, without any deduction from their rewards; and he who sets in Islam an evil precedent, there is upon him the burden of that and the burden of him also who acted upon it subsequently, without any deduction from their burden. ${ }^{55}$

Hadits di atas menceritakan bagaimana seseorang yang dalam keadaan memerlukan sesuatu mendapatkannya dari masjid Baginda Nabi saw melalui pertolongan Nabi dan para sahabatnya. Dari situasi itu dapat dilihat bahwa institusi masjid Nabi berfungsi dari sudut ekonominya, dimana mereka dapat memberikan sesuatu yang diperlukan oleh orang-orang yang memerlukan bantuan. Fungsi tersebut perlu diwujudkan dalam perancangan masjid pada masa kini dengan mewujudkan sesuatu yang memungkinkan ekonomi masjid tersebut dalam kondisi yang senantiasa stabil.

\section{Penutup}

Berdasarkan penilaian dan intepretasi yang dilakukan atas hadits-hadits Rasulullah saw, didapati bawa masjid pada zaman tersebut bukan saja diperuntukkan bagi kegiatan yang bersifat kerohanian dan ibadah semata-mata, tetapi ia juga berfungsi sebagai penggerak perkembangan masyarakat Islam dan agama Islam itu sendiri. Keberkesanan fungsinya pada zaman tersebut dapat dilihat pada penyebaran agama Islam ke seluruh pelosok dunia meskipun pada masa itu masjid baginda hanya dibina daripada batang pohon kurma dan beratapkan daundaun. Di balik kejayaan Rasulullah saw pada zaman tersebut, terdapat teladan bagi masyarakat Islam pada hari ini untuk membangun dan memakmurkan masjid dan memaksimumkan fungsinya sebagai satu pusat penggerak masyarakat Islam terkini dengan memenuhi pelbagai keperluan kerohanian dan juga fisikal. Dengan wujudnya masjid yang memainkan peranan penting tersebut diharap dapat membentuk dan menyatupadukan masyarakat Islam menjadi masyarakat yang disegani dan dipandang mulia di sisi masyarakat dan diridhai Penciptanya.

\section{Daftar Catatan dan Referensi}

1 Lihat Darwis Khudori, Critical Perception sementara yang kedua disebut sebagai Ideological Perception, kertas kerja pada The Third International Symposium on Islamic Expression in Indonesian Architecture, "Tectonic Dimension in Islamic Architectural Tradition in Indonesia, hal 60.

2 Lihat kertas kerja beliau: Ismail Serageldin, Contemporary Expressions of Islam in Buildings: The Religion and Secular, pada Seminar Internasional, Aga Khan Awards for Architecture, Jakarta \& Yogyakarta 15-19 Oktober 1990. 
3 Lihat prosiding Seminar Internasional, Aga Khan Awards for Architecture, Jakarta \& Yogyakarta 15-19 Oktober 1990, hal 28.

4 Lihat prosiding Seminar Internasional, Aga Khan Awards for Architecture, Jakarta \& Yogyakarta 15-19 Oktober 1990, hal 34.

5 Lihat kertas kerja beliau: Hassan-Uddin Khan, "The Overview of the Mosque, an Overview and Design Direction" pada Seminar Internasional, Aga Khan Awards for Architecture, Jakarta \& Yogyakarta 15-19 Oktober 1990, hal 109-126, lihat juga pembahagian menurut karateristik kawasan pada buku beliau: The Mosque: History, Architectural Development \& Regional Diversity (2002), New York: Thames \& Hudson.

6 Mohd. Tajuddin M Rasdi. 2003. Crisis in Islamic Architecture. KALAM Papers: Crisis in Islamic Architecture, Johor Bahru: Pusat Kajian Alam Bina Dunia Melayu (KALAM). h. 2.

7 Mohd. Tajuddin M Rasdi. 1999. Peranan, Kurikulum dan Reka Bentuk Masjid Sebagai Pusat Pembangunan Masyarakat. Skudai. UTM. h. 138.

8 Mohd. Tajuddin M Rasdi. 1999. Peranan, Kurikulum dan Reka Bentuk Masjid Sebagai Pusat Pembangunan Masyarakat. Skudai. UTM. h. 139.

9 Bukhari. 2002. Ringkasan Hadits Shahih Bukhari. Susunan semula Zabidi, Imam Ibn Ahmad. Terj. Drs. Achmad Zaidun. Jastaka:Pustaka Amani. Hadits ke-321. h. 194.

10 Abu Saif. 2009. Penjenamaan Semula Dakwah dan Imarah Masjid. Selangor. www. saifulislam.com.

11 Abu Saif. 2009. Penjenamaan Semula Dakwah dan Imarah Masjid. Selangor. www. saifulislam.com.

12 Abu Saif. 2009. Penjenamaan Semula Dakwah dan Imarah Masjid. Selangor. www. saifulislam.com.

13 Abu Saif. 2009. Penjenamaan Semula Dakwah dan Imarah Masjid. Selangor. www.saifulislam.com.

14 Faizal Ridzuan. 2009. Hotel dan Masjid Dalam Satu Kompleks. YADIM: Milenia Muslim. Bil. 85. h. 10 .

15 Faizal Ridzuan. 2009. Hotel dan Masjid Dalam Satu Kompleks. YADIM: Milenia Muslim. Bil. 85. h. 10.

16 Faizal Ridzuan. 2009. Hotel dan Masjid Dalam Satu Kompleks. YADIM: Milenia Muslim. Bil. 85. h. 14.

17 Salawati Haris. 2009. 6 Strategi Masjid Boleh Buat Duit. YADIM: Milenia Muslim. h. 16.

18 Salawati Haris. 2009. 6 Strategi Masjid Boleh Buat Duit. YADIM: Milenia Muslim. h. 18.

19 Salawati Haris. 2009. 6 Strategi Masjid Boleh Buat Duit. YADIM: Milenia Muslim. h. 19.
20 Mohd. Tajuddin M Rasdi. 1998. The Mosque as a Community Development Centre:Programme and Architectural Design Guidelines for Contemporary Muslim Societies. UTM Skudai:Tesis Sarjana. h. 17.

21 Shahih Muslim. Hadits ke-1387. h. 784.

22 Shahih Muslim. Hadits ke-1359. h. 772.

23 Shahih Muslim. Hadits ke-1387. h. 784.

24 KAC. Creswell. 1968. A Short Account of Early Muslim Architecture. Beirut: Librarie du Liban. h.5.

25 Mohd. Tajuddin M Rasdi. 1998. The Mosque as a Community Development Centre:Programme and Architectural Design Guidelines for Contemporary Muslim Societies. UTM Skudai:Tesis Sarjana. h. 275.

26 Shahih Muslim. Hadits ke-370. h. 159.

27 Shahih Muslim. Hadits ke-68. h. 35.

28 Shahih Muslim. Hadits ke-63. h. 33.

29 Shahih Bukhari. Hadits ke-303. h. 133,134.

30 Shahih Bukhari. Hadits ke-272. h. 120,121.

31 Shahih Muslim. Hadits ke-321. h. 194.

32 Shahih Bukhari. Hadits ke- 386. h. 164. Shahih Muslim. Hadits ke-244. h. 151,152. (Dinyatakan disini persamaan diantara Hadits Bukhari dan Muslim adalah pada matan Hadits dan maksudnya tetapi berbeza dalam penggunaan bahasa)

33 Shahih Bukhari. Hadits ke-299. h. 131,132.

34 Mohd. Tajuddin M Rasdi. 1998. The Mosque as a Community Development Centre:Programme and Architectural Design Guidelines for Contemporary Muslim Societies. UTM Skudai:Tesis Sarjana. h. 24.

35 Shahih Muslim. Hadits ke-1529. h. 858.

36 Shahih Muslim. Hadits ke-971. h. 525.

371 hasta $=1.5 \mathrm{ft}, 7$ hasta $=10.5 \mathrm{ft}=3150 \mathrm{~mm}$.

38 Shahih Bukhari. Hadits ke-497. h. 205,206.

39 Shahih Bukhari. Hadits ke-291. h. 128,129.

40 Shahih Bukhari. Hadits ke-478. h. 271.

41 Shahih Bukhari. Hadits ke-62. h. 33.

42 Shahih Muslim. Hadits ke-432. h. 248. Terdapat juga di dalam Hadits Bukhari pada Hadits ke286. h. 126, 127.

43 Shahih Bukhari. Hadits ke-286. h. 126,127.

44 Shahih Bukhari. Hadits ke-323. h. 141,142.

45 Shahih Bukhari. Hadits ke-69. h. 35.

46 Shahih Bukhari. Hadits ke-420. h. 176.

47 Shahih Bukhari. Hadits ke-87. h. 43.

48 Shahih Bukhari. Hadits ke-492. h. 203.

49 Shahih Bukhari. Hadits ke-4245. h. 152.

50 Shahih Bukhari. Hadits ke-218. h. 93.

51 Shahih Bukhari. Hadits ke-277. h. 122,123.

52 Shahih Bukhari. Hadits ke-1332. h. 547.

53 Hadis ke-1393. Himpunan Hadis Shahih oleh Bukhari dan Muslim. h. 819 dan 820.

54 Shahih Bukhari. Hadits ke-68. h. 35.

55 Shahih Muslim. Volume II. h. 48. 